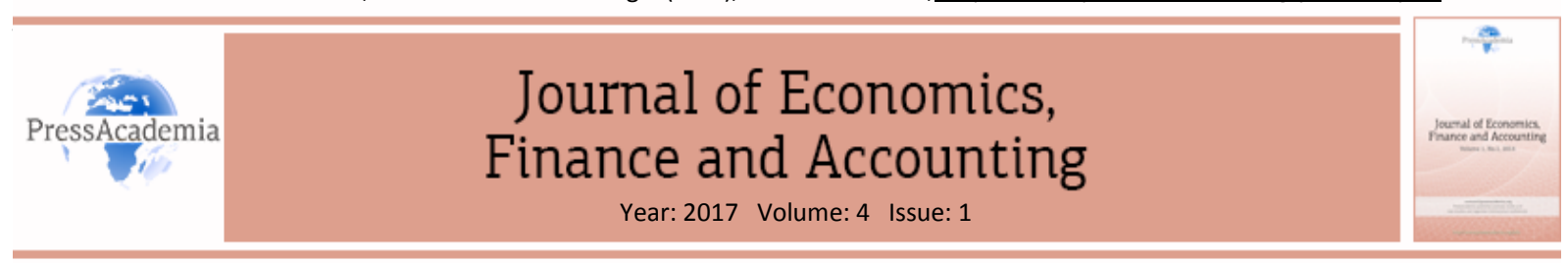

\title{
CAPITAL INCREASE IN INCORPORATED COMPANIES: REVIEW OF TURKISH BANKING SECTOR
}

\author{
DOI: 10.17261/Pressacademia.2017.365 \\ JEFA-V.4-ISS.1-2017(5)-p.48-69
}

\author{
Suphi Aslanoglu ${ }^{1}$, Seyfi Yildiz ${ }^{2}$, Selim Cengiz ${ }^{3}$ \\ ${ }^{1}$ Kırıkkale University, Department of Business Administration, 71000, Kırıkkale,Turkey, s aslanoglu@hotmail.com \\ ${ }^{2}$ Anadolu Agency, 06000, Ankara, Turkey, seyfi.yildiz@aa.com.tr \\ ${ }^{3}$ Cankırı Karatekin University, Department of Banking and Finance, 18000, Cankırı, Turkey, scengiz@karatekin.edu.tr
}

To cite this document

Aslanoglu, S. and S. Yıldız and S.Cengiz, (2017). Capital increase in incorporated companies: revıew of Turkish bankıng companıes, Journal of Economics, Finance and Accounting (JEFA), V.4, Iss.1, p.48-69.

Permemant link to this document: http://doi.org/10.17261/Pressacademia.2017.365

Copyright: Published by PressAcademia and limited licenced re-use rights only.

\begin{abstract}
Purpose - In review of academic researches regarding capital increase in the country, it becomes clear that there are few studies observing the factors affecting corporations' capital structure and decisions on increase. Moreover, there is almost no study concerning capital structure and capital increase in banking sector which is vital for financial markets. Consequently, the purpose of this study is to scrutinize in various time periods, the capital structure and capital increases in Turkish banking sector as well as the factors behind them. Insomuch that some knowledge shall be gained pertaining to the capital structure and capital increases in Turkish banking sector within different periods.

Methodology - This study has utilized content analysis method in order to review levels of capital increase and the factors forming the capital structure of Turkish banking sector. In scope of the purpose of this study, financial accounts pertaining to the periods of 2010 and 2015 of 13 banks which are perpetually active in BIST (Istanbul Stock Exchange) have been scrutinized. The data required for the study has been obtained from the activity reports of the banks plus KAP (public disclosure platform).

Findings - It has been ascertained that the banks subject to the study increase their capitals mostly by means of internal resources and rarely via external sources.

Conclusion - It has been gathered that the banks keep operating with high profits and preserve the majority of their period incomes in shareholders' equity by increasing capital or transferring to the reserves. Additionally, it has been determined that the banks included in the study have oriented a very small part of their equity to such fixed investments as real assets and participations, as well as they have remarkably high equity and accordingly a strong structure of liquid assets. On a general basis, it might be suggested that the banks have had high equity in the course of years.
\end{abstract}

Keywords: Banking sector, capital increase, internal resources, Turkish Business Law, equity finance.

JEL Codes: G32, K22, M41.

\section{ANONIM ŞIRKETLERDE SERMAYE ARTIRIMI: TÜRK BANKACILIK SEKTÖRÜNDE BİR INNCELEME}

\section{ÖZET}

Amaç - Ülkemizde sermaye artııımı konusunda yapılan akademik çalışmalar incelendiğinde, şirketlerin sermaye yapısını ve artıım kararlarını etkileyen faktörleri inceleyen çalışmaların sayısı çok kısıtlı olduğu anlaşılmaktadır. Özellikle finansal piysaların olmazsa olmazı olan bankacııık sektöründe sermaye yapısı ve artıımı konusunda yok denecek kadar az sayıda çalışma bulunmaktadır. Bu bağlamda çalışmanın amacı, Türk bankacııık sektörünün sermaye yapısını ve artıımlarını ile bunlara neden olan faktöleri dönemler itibariyle incelemektir. Bu sayede Türk bankaılık sektörünün dönemler itibariyle sermaye yapısını ve özeliklede sermaye artırım politikaları hakkında bilgi sahibi olmaktır.

Yöntem - Türk bankalık sektörünün sermaye yapısını oluşturan faktörleri ve sermaye artırım düzeylerini incelemek için yapılan bu çalışmada içerik analizi yöntemi kullanılmıştır. Çalışmanın amacı kapsamında, BisT’te sürekli bir şekilde faaliyet gösteren 13 bankanın 2010 2015 dönemlerine ait finansal tabloları incelenmiştir. Çalışmanın verilerine ise KAP (kamuyu aydınlatma platformu) ve bankaların faaliyet raporlarından ulaşılmışır. 
Bulgular - Analiz kapsamında incelenen bankaların sermaye artıımlarını çok azda olsa dış kaynaklardan ancak genellikle iç kaynaklardan faydalanarak yaptıkları tespit edilmiştir.

Sonuç - Bankaların faaliyetlerini yüksek kârlılıkla sürdürmekte olduğu ve dönem kârlarının büyük bölümünü sermaye artııııı veya yedeklere aktarım şeklinde özkaynaklar içinde muhafaza ettiği sonucuna ulaşılmıştır. Ayrıca analiz kapsamındaki bankaların özkaynaklarının çok küçük bir bölümü sabit kıymet ve iştirakler gibi sabit yatırımlara yönlendirilmiş oldukları ve özsermayelerinin oldukça yüksek olduğu ve bunun soncunda da likit yapılarının güçlü olduğu tespit edilmiştir. Genel olarak analiz kapsamındaki bankaların yıllar itibariyle yüksek özkaynak gücüne sahip oldukları söylenebilir.

Anahtar Kelimeler: Bankacılık sektörü, sermaye artırımı, iç kaynaklar, Türk Ticaret Kanunu, özkaynaklar. JEL Kodları: G32, K22, M41.

\section{Giriş̧}

Sermaye kavramı, kullanıldığı alana göre değişen farklı anlamlara sahiptir. Ekonomi alanında kullanıldığında sermaye, emeğin verimini artıran ve önceden üretilmiş olan üretim araçları olarak tanımlanır (Ünsal, 2004, s.8). Muhasebe açısından sermaye, esas sermaye ve öz sermaye olarak ikili ayrıma tabidir. Esas sermaye, bir işe ayrılan para veya para ile ölçülebilen değer olarak anlaşılır. Öz sermaye ise işletmecinin işletme için ayırdığı toplam değeri ifade etmektedir (Koç, 2001, s. 389). Şirketler hukukunda ise sermaye, genel olarak bir ticari işletme veya ortaklığın amacına ulaşmak için işletme veya ortaklığa tahsis edilen maddi, gayri maddi ve para ile ölçülebilen değerler toplamı olarak ifade edilir. Paydaşların sermaye oluşturmak için getirdikleri payları, uzun vadeli yatırım olarak nitelemek de mümkündür (Akkale, 2013, s. 1-2). Diğer bir ifadeyle sermaye, bilançonun pasif kısmında yer alan, karşısında-aktif kısımda- ise kuruluşta en az o kadar nakit, mal veya hak şeklinde bir malvarlığı olan, şirketin çapını ifade eder (Biçer, 2010, s. 5).

Anonim şirketlerde sermaye kavramı çoğu zaman esas sermayeyi kastetmek amacıyla kullanılır. Oysa sermaye kavramı esas sermayeyi de içine alan daha geniş bir kavramdır. Esas sermaye kavramına, kanunda birçok kez yer verilmiş olmasına rağmen ne 6762 sayılı ne de 6102 sayılı TTK'da tanımı yapılmamıştır. Esas sermayeyi anonim şirketin tescilinden önce, şirket sözleşmesi çerçevesinde, ortakların getirmeyi taahhüt ettikleri malvarlığı değerlerinin toplamı olarak tanımlanabilir (Çağlar, 2010 , s. 6). TTK m. 332/1'de en az 50.000 TL olarak belirlenmiştir. Esas sermayenin asgari miktarının kanunda belirtilmesinin sebebi, alacaklıların haklarının korunmasıdır. Çünkü anonim şirketlerde şirket, alacaklılara karşı yalnız malvarlığı ile sorumludur (TTK m. 329/1). Bu suretle şirketle hukuki ilişkiye giren kişiler, hiç değilse esas sermaye kadar bir malvarlığının şirkette bulunduğuna güvenebilirler. Şirkete kredi vermeyi düşünen bankalar da esas sözleşmedeki esas sermaye miktarına bakarak kredi verip vermeyeceklerine karar verebilirler (Saraç, 2009, s. 2).

Kuruluş sırasında öngörülen sermayenin yetersiz kalması, iş hacminin genişletilmesi gibi nedenlerle anonim şirket mevcut sermayesi ihtiyacı karşılayamaz duruma gelebilir. Anonim şirketlerin zaman zaman oluşan finansman ihtiyaçlarına buldukları çözümlerden biri, sermaye artırımıdır. Sermaye artırımları sayesinde şirket, yüksek faizli veya kısa vadeli kredi kullanmak yerine ihtiyaç duyduğu finansmanı şirketten nakit çıkışı olmadan sağlayabilir. Şirket sermayesini sabit sistemde esas sermaye artırımı veya kayıtlı sermaye sistemi ile de artırabilir. Ancak sabit sistemde esas sermaye artırımında karar organı genel kuruldur. Genel kurulun toplanması ise zor ve çok sayıda formalite ile mümkündür. Bu soruna çözüm olarak bulunan kayıtlı sermaye artırımında ise genel kurul münhasır yetkisi olan sermaye artırımını yönetim kuruluna devretmektedir. Ayrıca her iki sistem de pay senedi ile değiştirilebilir tahvil uygulaması ve çalışanların şirkete katılımı için uygun değildir (Güçlü, 2013, s. 1).

Anonim şirketlerde sermaye artırımı yapabilmesi için bazı koşulların yerine getirilmesi gerekir. TTK'Ya göre, iç kaynaklardan yapılan sermaye artırımı hariç olmak üzere, payların nakdi bedelleri tamamen ödenmediği sürece sermaye artırılamaz. 6762 sayılı eski TTK esas sermayeye karşılık olan hisse senetlerinin bedelleri tamamen ödenmedikçe, umumi heyetin yeni hisse senetleri çıkarmak suretiyle sermaye artıramayacağını öngörmekte iken, 6102 sayılı hâlihazırdaki TTK'da bu hususta esneklik sağlanmıştır. 456. maddeye göre, sermayeye oranla önemli sayılmayan tutarların ödenmemiş olması sermaye artırımını engellemez. Öte yandan, hisseleri borsada işlem gören şirketler, sermaye artıım kararı aldıklarında Kamuoyu Aydınlatma Platformu (KAP) aracılı̆̆ıyla bunu duyurmak zorundadırlar. Duyurunun yapılmasından önceki ve sonraki günlerde işlem hacmi ve fiyatlarındaki ani dalgalanmalar nedeni ile normalden uzaklaşma durumu olarak ifade edilebilen "anomali"ler oluşmaktadır. Ülkemizde sermaye artırımı konusunda yapılan akademik çalışmalar genellikle sermaye artırımının hisse fiyatlarına etkisi üzerine yoğunlaşırken, sermaye artırım kararlannı etkileyen faktörler ve nedenleri ihmal edilmiştir. Özellikle finansal piysaların olmazsa olmazı olan bankacılık sektöründe sermaye artırımı konusunda yok denecek kadar az çalışma vardir. 
Bu kapsamda çalışmanın amacı, Borsa İstanbul (BIST) faaliyet gösteren bankaların sermaye artırım kararlarını, şekillerini ve hangi yıllarda ne kadar sermaye artırımı yaptıklarını belirlenmek işin ampirik bir çalışma sunmaktır. 2010-2015 yılları arasında BiST'te yer alan 13 bankaya ait verileri analiz edilmiştir. Çalışmanın bundan sonraki bölümleri; konunun daha bütüncül bir yaklaşımla anlatabilmek için öcelikle, sermaye artırımı, anonım şırketlerde sermaye artırımları ve sermaye artırım türleri teorik olarak anlatıldıktan sonra, BIST bankacilik sektöründe faaliyette bulunan bankaların sermaye artırımları analiz edilmiştir. Sonraki bölümde ise çalışmanın bulgularına, genel bulguların değerlendirilmesine ve sonuçlarına yer verecek şekilde dizayn edilmiştir.

\section{GENEL OLARAK SERMAYE ARTIRIMI}

Sermaye artırımı anonim şirketlerde, şirket esas sözleşmesinde esas (kayıtlı) sermaye olarak gösterilen sabit tutarın veya değerin artırımasıdır. Diğer bir ifadeyle sermaye artırımı, bir şirketin esas (kayıtı) sermayesine karşılık olan hisse senetlerinin bedelleri ödendikten sonra genel kurul (yönetim kurulu) kararı ile yeni hisse senedi çıkarılarak şirket sermayesinin arttııımasıdır. Sermaye artırımı, yeni paydaşların katılması veya mevcut pay sahiplerinin rüçhan haklarını kullanarak yeni pay almaları sonucu dış kaynaklardan gerçekleşebileceği gibi, şirketin mamelekinde bulunan bazı kaynakların kullanımıyla yapılan artırım sayesinde, ortaklık malvarlı̆̆ını büyütmeden, muhasebe işlemleri sonucunda, esas sermaye malvarlığı değerine yaklaştırılması suretiyle iç kaynaklardan yapılabilir (Moroğlu, 2003, s. 141). íç kaynaklardan artırım ile şirketin yıllık kâr oranını ve pay senetleri kurunun düşürülmesi, kar dağıtımında dengenin sağlanması ve ortaklık kredisinin yükseltilmesi amaçlanır (Bahtiyar, 1996, s. 128). İç kaynakları kullanmak vasıtasıyla sermaye artırımını sağlamak için kullanılacak kalemler, yedek akçeler, önceki yıldan artırılan kâr, dağıtılmamış son yıl kârı ve katılma payları ya da taşınmaz satışından doğan kazançlardır (Bahtiyar, 1996, s. 129-138). İ̧ kaynaklardan sermaye artırımı sonucunda çıkarılan pay senetlerine, ödemesiz pay senetleri de denmektedir (İmregün, 1989, s. 449; Moroğlu, 2003, s. 184 ). İç kaynaklardan sermaye artırımında, halka satış söz konusu olmasa da, senet çıkarma zorunluluğu, bu yöntem kullanılarak gerçekleştirilen kayıtlı sermaye artırımı için gereklidir Bahtiyar, 1996, s. 141).

İç kaynaklardan yapılan artırım hariç, payların nakdî bedelleri tamamen ödenmediği sürece sermaye artırılamaz. Sermayeye oranla önemli sayılmayan tutarların ödenmemiş olması sermaye artırımını engellemez. Artırıma, esas sermaye sisteminde genel kurul; kayıtlı sermaye sisteminde, yönetim kurulu karar verir. Esas sözleşmenin ilgili hükümlerinin, gerekli olduğu hâllerde izni alınmış bulunan değişik şekli, genel kurulda değiştirilerek kabul edilmişse, bunun Gümrük ve Ticaret Bakanlığınca onaylanması şarttır. Artırım, genel kurul veya yönetim kurulu kararı tarihinden itibaren üç ay içinde tescil edilemediği takdirde, genel kurul veya yönetim kurulu kararı ve alınmışsa izin geçersiz hâle gelir. Sermaye artıımı ile ilgili 6102 sayılı TTK ile yönetim kurulu beyanında; sermaye artırımında nakdi sermaye koyuluyorsa; artırılan kısmın tamamen taahhüt edildiği, kanun veya esas sözleşme gereğince ödenmesi gereken tutarın ödendiği, ayni sermaye koyuluyor ve bir ayın devralınıyorsa bunlara verilecek karşılığın uygun olduğu, bir borcun takası söz konusu ise; bu borcun varlığı, geçerliliği ve takas edilebilirliği, sermayeye dönüştürülen fonun veya yedek akçenin serbestçe tasarruf olunabilirliği, rüçhan hakları sınırlandırılmış veya kaldırılmışsa bunun sebepleri, miktarı ve oranı, kullanılmayan rüçhan haklarının kimlere, niçin, ne fiyatla verildiği hakkında açıklamalar yer almalıdır. Sermaye artırımı, iç kaynaklardan sermaye artırımı şeklinde gerçekleşmekte ise, yönetim kurulu beyanında ayrıca iç kaynaklardan yapılan sermaye artırımının hangi kaynaklardan karşılandığı, bu kaynakların gerçekliği ve şirket malvarlığı içinde var oldukları konusunda garanti vermelidir. Şartlı sermaye artıımının söz konusu olduğu durumlarda ise, şartı sermaye artırımının ve uygulamasının kanuna uygunluğu belirtilir (http://www.hitasymm.com.tr/yeni-turk-ticaret-kanunu-ile-anonim-sirketlerde-sermaye-ve-sermaye-artirimi-ile-ilgiligetirilen-yenilikler-).

TTK, Sermaye Piyasası Kanunu'na göre halka açık şirketlerde uygulanmakta olan kayıtlı sermaye sisteminin halka açık olmayan anonim şirketlerde de uygulanabileceğini hüküm altına almıştır. TTK'ya göre, esas sermaye 50.000 TL'den ve kayıtlı sermaye sistemini kabul etmiş bulunan halka açık olmayan anonim şirketlerde başlangıç sermayesi $100.000 \mathrm{TL}$ 'den aşağı olamaz. Sermaye artırımına esas sermaye sisteminde genel kurul, kayıtlı sermaye sisteminde ise yönetim kurulu karar verir. Esas sermaye sisteminde sermaye artırımı, kayıtlı sermaye sisteminde ise kayıtlı sermaye tavanı artırımı ile ilgili olarak esas sözleşmede değişiklik yapılması gerekmektedir. Sermaye artırımı, iç kaynaklardan sermaye artırımı şeklinde gerçekleşmekte ise, yönetim kurulu beyanında ayrıca iç kaynaklardan yapılan sermaye artırımının hangi kaynaklardan karşılandığı, bu kaynakların gerçekliği ve şirket malvarlığı içinde var oldukları konusunda garanti vermelidir. Şartlı sermaye artırımının söz konusu olduğu durumlarda ise, şartlı sermaye artırımının ve uygulamasının Kanun'a uygunluğu belirtilir. Yukarıda verilen açıklamalar kapsamında bir şirketin esas sermaye artırımına gitmesinde çeşitli amaçları olabilir. Bu amaçlar şu şekilde özetlene bilir (Eren, 2001, s. 30; Güçlü, 2013, s. 7);

- Şirketin yeni atılımlar yapabilmesi için finansman ihtiyacı olabilir. Böyle bir durumda şirket, borç almak veya yüksek faizli ve kısa vadeli banka kredisi kullanmak yerine sermaye artırımına gitmeyi tercih edebilir.

- Şirketin faaliyetlerinin reel büyümesi sonucu gereken fon ihtiyacını gidermek,

- Yüksek enflasyon şartlarında erimiş olan sermayelerini güçlendirmek.

- Şirket vadesi gelmiş borçlarını nakit olarak ödemek yerine, sermaye artırımına gidip alacaklılara pay senedi verebilir. 
- Yeni yatırımlar yapmak için.

- Şirketin itibar kaybına uğramasını engellemek için, kanuni yedek akçeler ve borçlar sermayeye dönüştürülerek iç kaynaklardan sermaye artırımı yapılabilir.

- Halka açık olmayan bir anonim şirket, yaptığı bir sermaye artırımında pay sahiplerinin yeni pay alma hakkını tamamen veya kısmen kaldırarak halka açılmayı amaçlayabilir.

- Şirket, zararla kaybolan sermayenin tamamlanması, yeni yavru şirketler ve şubeler kurulması gibi nedenlerle de esas sermaye artırımına gidebilir.

- Karın dağıtılmaması ve kar payı yerine bedelsiz hisse senedi dağıtılması ve bu şekilde vergi avantajı sağlanması için de sermaye artırımı tercih edilebilir.

Öte yandan, kural olarak şirketlerde sermaye artırımına gidilmesi zorunlu olmayıp, şirketin tercihine bırakılmıştır. Ancak bazı özel durumlarda kanun sermaye artırımına gidilmesini zorunlu hale getirmiştir. Örneğin iki şirket devralma suretiyle birleşiyorsa, devralan şirket, sermayesini, devrolunan şirketin ortaklarının haklarının zarar görmemesi için gerekli olan düzeyde artırmak zorundadır (TTK m. 142/1). Buna benzer başka bir örnek de 6103 sayılı TTK'nın Yürürlüğü ve Uygulama Şekli Hakkında Kanun m. 20'de yer almaktadır. Bu hükme göre, anonim ve limited şirketler, TTK'nın yayımlandığı tarihten itibaren üç yıl içinde sermayelerini, söz konusu Kanun'un 332 ve 580 inci maddelerinde öngörülen tutarlara kadar artırmadıkları takdirde sürenin sonunda infisah etmiş sayılırlar.

Ayrıca şirketin esas sermeye artırımına gitmesinde, mutlaka bir gerekçesinin olması şart değildir. Esas sermaye artırımı, şirkete tanınmış bir hak olduğundan, bunun esas sözleşmede ayrıca belirtilmesine gerek yoktur. Bu hakkın kullanımı için haklı bir sebebin olması da gerekmez. Sırf sebebi belirtilmedi diye esas sermaye artırımı geçersiz olmaz. Ancak kanun ve sözleşme hükümlerine ve özellikle dürüstlük kuralına aykırı olarak yapılan sermaye artırımları iptal edilebilir (TTK m. 445). Özellikle oyların çoğunluğunu ellerinde bulunduran ortakların, azınlık pay sahiplerini zarara uğratmak için, şirketin ihtiyacının çok üstünde sermaye artırımı yapmaları halinde dürüstlük kuralına aykırılık vardır. Ayrıca eşit işlem ilkesine veya hakların başkalarına en az zarar verecek şekilde kullanılması ilkelerine aykırı olarak yapılan sermaye artırımları da geçersizdir. Pay sahiplerinin esas sermaye artırımına katılmaları zorunlu değildir. Ancak esas sermayenin artırılmasıyla pay sahiplerinin pay oranları, dolayısıyla da, şirketteki idari ve mali haklara katılımları azalacağı için sermaye artırımına katılmaları kendi menfaatlerinedir. Yargıtay'ın verdiği bir karara göre pay sahipleri, yeni pay alma hakkından yararlanacak durumda olmadıklarında da, sermaye artırımına tahammül göstermek zorundadırlar. Çünkü bir kısım pay sahibinin, yeni pay alamayacak durumda olması, tek başına dürüstlük kuralına aykırılık oluşturmaz (Biçer, 2010, s. 23; Saraç, 2009, s. 5; Kaya, 1997, s. 26, Güçlü, 2013, 9).

\section{ANONIM ŞIRKETLERDE SERMAYE ARTIRIMI}

Anonim şirketlerde sermaye artırılması ile ilgili hükümlere TTK'nın 456 ile 472'nci maddeleri arasında yer verilmiş bulunmaktadır. TTK'nın 456'ncı maddesi hükmü uyarınca, iç kaynaklardan yapılan artırım hariç, payların nakdi bedelleri tamamen ödenmediği sürece sermaye artırılamaz. Ödenmemiş tutar, mevcut sermayeye oranlandığında, sermaye miktarına göre düşük bir oranı ifade etmelidir (Pulaşlı, 2013, s. 48). Artırıma, esas sermaye sisteminde genel kurul; kayıtlı sermaye sisteminde ise yönetim kurulu karar verir. Artırım, genel kurul veya yönetim kurulu kararı tarihinden itibaren üç ay içinde tescil edilemediği takdirde, genel kurul veya yönetim kurulu kararı geçersiz hale gelir.

\subsection{Yönetim Kurulu Beyanı}

TTK'nın 457'nci maddesi hükmü uyarınca; Yönetim Kurulu tarafından sermaye artırımının türüne göre bir beyan hazırlanır. Beyan, bilgiyi açık, eksiksiz, doğru ve dürüst bir şekilde verme ilkesine göre hazırlanır. Bu beyanda;

- Nakdi sermaye konuluyorsa; artırılan kısmın tamamen taahhüt edildiği, kanun veya esas sözleşme gereğince ödenmesi gerekli tutarın ödendiği,

- Ayni sermaye konuluyor veya bir ayın devralınıyorsa bunlara verilecek karşılığın uygun olduğu,

- Bir borcun takası söz konusu ise bu borcun varlığı, geçerliliği ve takas edilebilirliği,

- Sermayeye dönüştürülen fonun veya yedek akçenin serbestçe tasarruf olunabilirliği,

- Rüçhan hakları sınırlandırılmış veya kaldırıımışsa bunun sebepleri, miktarı ve oranı; kullanılmayan rüçhan haklarının kimlere, niçin, ne fiyatla verildiği hakkında açıklamalar yer almalıdır.

Yine söz konusu beyanda, iç kaynaklardan yapılan sermaye artırımının hangi kaynaklardan karşılandığı, bu kaynakların gerçekliği ve şirket malvarlığı içinde var oldukları konusunda garanti verilir. Şartlı sermaye artırımının ve uygulamasının kanuna uygunluğu belirtilir. Sermaye artıımını inceleyen işlem denetçisi ile hizmet sunanlara ve diğer kimselere ödenen ücretler, sağlanan menfaatler hakkında, emsalleriyle karşılaştırma yapılarak, bilgi verilir. Pay senedi çıkarılmasına ilişkin yetkinin, kısmen veya tamamen başka bir organ veya kişiye devri mümkün değildir. Bu yönde yapılan devir, sisteme aykırıdır ve geçersizdir (Tekinalp, 2011, s. 49). Pay alım hakkının yönetim kurulu tarafından keyfi ve eşit işlem ilkelerine aykırı kullanımı, sorumluluk sebebidir (Moroğlu, 2003, s. 185). 


\subsection{Sermaye Artırımı Yöntemleri}

6102 sayılı TTK'da anonim şirketlerde sermaye artırımı üç ana başlıkta sınıflandırılmıştır.

- Sermaye taahhüdü yoluyla artırımı

- Iç kaynaklardan (bedelsiz) sermaye artırımı

- Şarta bağlı sermaye artırımı

\subsubsection{Sermaye Taahhüdü Yoluyla Artırımı}

Sermaye taahhüdü yoluyla sermaye artıımına gidildiğinde, işletmeye girecek para veya para dışındaki ekonomik değerler karşılı̆̆ında yeni hisse senetleri ihraç edilir. 6102 sayılı TTK'da sermaye taahhüdü yoluyla sermaye artırımı; esas sermaye sisteminde sermaye artırımı ve kayıtlı sermaye sisteminde sermaye artırımı olmak üzere iki başıkta düzenlenmiştir.

\section{Esas Sermaye Sisteminde Sermaye Artırımı}

Esas sermaye sisteminde sermaye artırımına genel kurul karar verir. TTK'nın 459'uncu maddesine göre, artırılan sermayeyi temsil eden payların tamamı ya değişik esas sözleşmede ya da iştirak taahhütnamelerinde taahhüt edilir. Yazılı olarak hazırlanan iştirak taahhütnamesi; taahhüt edilen payların sayılarını, itibari değerlerini, cinslerini, gruplarını, peşin ödenen tutarı, taahhütle bağıı olunulan süreyi ve varsa çıkarma primi ile taahhüt sahibinin imzasını içerir.

Esas sermaye sisteminde sermaye artırımında, nakden taahhüt edilen payların itibari değerlerinin en az yüzde yirmi beşi esas sözleşmenin değiştirilmesine iliş̧in genel kurul kararının ticaret siciline tescilinden önce, gerisi de tescili izleyen yirmi dört ay içinde ödenir. Ödemeler şirket adına açılacak özel bir hesaba yatırılır. Esas sermaye sisteminde ayni sermaye konulmak suretiyle de sermaye artırılabilir. Üzerlerinde sınırlı bir ayni hak, haciz ve tedbir bulunmayan, nakden değerlendirilebilen ve devrolunabilen, fikri mülkiyet hakları ile sanal ortamlar da dahil, malvarlığı unsurları ayni sermaye olarak konulabilir. Hizmet edimleri, kişisel emek, ticari itibar ve vadesi gelmemiş alacaklar sermaye olamaz. Esas sermaye sisteminde payların halka arz edilmesi yoluyla da sermaye artırımına gidilebilir. Bu durumda değiştirilmiş esas sözleşmede nakit karşılığı olarak taahhüt edilmiş paylar, değişik esas sözleşmenin ticaret siciline tescilinden itibaren iki ay içerisinde halka arz edilmelidir.

\section{Kayıtlı Sermaye Sisteminde Sermaye Artırımı}

Kayıtlı sermaye, esas sözleşmede sermayenin yönetim kurulu tarafından artırılabileceği tavan miktarı gösterir. Kayıtlı sermaye ne ödenmiştir ne de ödeneceği taahhüt edilmiştir (Tekinalp, 2011, s. 69-70). Kayıtlı sermaye miktarı, yönetim kurulunun çıkarabileceği en fazla sermayenin sınırını çizer. Kayıtlı sermaye miktarına ulaşılmakla, yönetim kurulunun sermaye artırma yetkisi son bulur. Kayıtlı sermaye miktarının yükseltilebilmesi için şirket esas sözleşmesinde değişikliğe gidilmesine ihtiyaç duyulur (Moroğlu, 2003, s. 1).

TTK'nın 460'ıncı maddesi hükmüne göre, halka açık olmayan anonim şirketlerde, yönetim kuruluna esas sözleşmede belirtilmiş olan kayıtlı sermaye tavanına kadar sermayeyi artırma yetkisi verilebilir. Bu durumda yönetim kurulu kararı ile sermaye artırımı TTK ve esas sözleşmede belirtilen yetki sınırları çerçevesinde gerçekleştirilebilir. Yönetim kuruluna bu yetki en çok 5 yıl için tanınabilir. Kayıtlı sermaye sisteminde, sermaye yönetim kurulu kararı ile artırılır. Bunun için yönetim kurulu önce sermaye artırımının gerektirdiği şekilde esas sözleşmenin ilgili maddesinin yeni şeklini hazırlar. Yönetim kurulu kararında; artırılan sermaye tutarını, çıkarılacak yeni payların itibari değerlerini, sayılarını, cinslerini, primli ve imtiyazlı olup olmadıklarını, rüçhan hakkının sınırlandırılıp sınırlandırılmadığını, kullanılma şartları ile sürelerini belirtir. Yönetim kurulu esas sözleşmenin yeni metnini, sermayenin artırılmasına ilişkin yönetim kurulu kararını, imtiyazlı paylara ve rüçhan haklarına ilişkin sınırlamaları, prime dair kayıtları ve bu kararın uygulanması hakkındaki kuralları esas sözleşmede öngörüldüğü şekilde ilan eder ve internet sitesinde yayınlar. TTK'nın 460/5'inci maddesi hükmü uyarınca, pay sahipleri ve yönetim kurulu üyeleri, kanun veya esas sözleşme hükümlerine ve özellikle dürüstlük kurallarına aykırı olan yönetim kurulu kararları aleyhine, kararın ilan tarihinden itibaren bir ay içinde iptal davası açabilirler. Yine TTK'nın 460/4'üncü maddesine göre, yönetim kurulunun, imtiyazlı veya itibari değerinin üzerinde pay çıkarabilmesi ve pay sahiplerinin yeni pay alma haklarını sınırlandırabilmesi için esas sözleşmeyle yetkilendirilmiş olması şarttır.

\subsection{2. İ̧̧ Kaynaklardan (Bedelsiz) Sermaye Artırımı}

İ̧ kaynaklardan sermaye artırımı TTK'nın 462'nci maddesinde düzenlenmiştir. Buna göre; esas sözleşme veya genel kurul kararıyla ayrılmış ve belli bir amaca özgülenmemiş yedek akçeler ile kanuni yedek akçelerin serbestçe kullanılabilen kısımları ve mevzuatın bilançoya konulmasına ve sermayeye eklenmesine izin verdiği fonlar sermayeye dönüştürülerek sermaye iç kaynaklardan artırılabilir. Sermayenin artırılan kısmı, iç kaynaklardan karşılayan tutarın şirket bünyesinde gerçekten varolduğu, onaylanmış yıllık bilanço ve işlem denetçisinin vereceği açık ve yazılı bir beyanla doğrulanır. Bilanço tarihinin 
üzerinden altı aydan fazla zaman geçmiş olduğu takdirde, yeni bir bilanço çıkarılması ve bunun işlem denetçisi tarafından onaylanmış olması şarttır.

\section{Esas sözleşme veya genel kurul kararıyla ayrılmış ve belli bir amaca özgülenmemiş yedek akçeler}

TTK'nın 521 ve 522'nci maddelerinde anonim şirketin esas sözleşmesine göre ayrılması gereken yedek akçeler "şirketin kendi isteği ile ayırdığı yedek akçeler" başığı altında belirlenmiştir. TTK'nın eski halinde bu nitelikteki yedek akçeler "ihtiyari yedek akçeler" olarak ifade edilmekteydi. TTK'nın 521'inci maddesine göre, yedek akçeye yıllık karın \% 5'inden fazla bir tutarın ayrılacağı ve yedek akçenin ödenmiş sermayenin \% 20 'sini aşabileceği hakkında sözleşmeye hüküm konabilir. Esas sözleşme hükümleri ile yasal sınırlar üzerinde ayrılan kısma "statü yedekleri" denilmektedir ve bu yedekler sermayeye ilave edilebilir. Diğer yandan, esas sözleşmede şirketin yöneticileri, çalışanları ve iş̧̧ileri için yardım kuruluşları kurulması amacı ile de yedek akçe ayrılabilir. Ancak bu şekilde ayrılan yedek akçeler belirli bir amaca özgülenmiş olmaları nedeniyle iç kaynaklardan sermaye artırımında kullanılamazlar. TTK'nın 523'üncü maddesinin 2'nci fıkrası hükmüne göre; “Genel kurul;

a) Aktiflerin yeniden sağlanabilmesi için gerekliyse,

b) Bütün pay sahiplerinin menfaatleri dikkate alındığında, şirketin sürekli gelişi ve olabildiğince kararlı kar payı dağıtımı yönünden haklı görülüyorsa, Kanunda ve esas sözleşmede öngörülenlerden başka yedek akçe ayrılmasına da karar verebilir." "Olağanüstü yedek akçe" adı verilen bu nitelikteki yedek akçeler de iç kaynaklardan yapılacak sermaye artırımında kullanılabilir.

\section{Kanuni yedek akçelerin serbestçe kullanılabilen kısımları}

Sermaye şirketleri, özellikle anonim şirketler yasal olarak karlarından belli bir kısmını yedek akçe olarak ayırmak durumundadırlar. TTK'da kanuni yedek akçeler; "Genel Kanuni Yedek Akçe” ile "Şirketin İktisap Ettiği Kendi Pay Senetleri İçin Ayrılan Yedek Akçe ve Yeniden Değerleme Fonları" olmak üzere ikiye ayrılmıştır.

\section{i. Genel Kanuni Yedek Akçeler}

TTK'nın 519'uncu maddesi hükmüne göre, yıllık karın \% 5'i, ödenmiş sermayenin \% 20'sine ulaşıncaya kadar genel kanuni yedek akçe ayrıır. Bu şekilde ayrılan yedek akçeye "1.tertip yedek akçe" adı verilir. Yine 519'uncu maddeye göre, birinci fıkradaki sınıra ulaşıldıktan sonra da;

a. Yeni payların çıkarılması dolayısıyla sağlanan primin, çıkarılma giderleri, itfa karşılıkları ve hayır amaçlı ödemeler için kullanılmamış bulunan kısmı,

b. Iskat sebebiyle iptal edilen pay senetlerinin bedeli için ödenmiş olan tutardan, bunların yerine verilecek yeni senetlerin çıkarılma giderlerinin düşülmesinden sonra kalan kısmı,

c. Pay sahiplerine yüzde beş oranında kar payı ödendikten sonra, kardan pay alacak kişilere sağlanan toplam tutarı \% $10^{\prime}$ u genel kanuni yedek akçeye eklenir.

Genel kanuni yedek akçe sermayenin veya çıkarılmış sermayenin yarısını aşmadığı takdirde, sadece zararların kapatılmasına, işlerin iyi gitmediği zamanlarda işletmeyi devam ettirmeye veya işsizliğin önüne geçmeye ve sonuçlarını hafifletmeye elverişli önlemler alınması için kullanılabilir (Şengür, 2011, s. 97-119).

\section{ii. Şirketin İktisap Ettiği Kendi Pay Senetleri İçin Ayrılan Yedek Akçe ve Yeniden Değerleme Fonları}

6102 sayılı TTK ile, anonim şirketlerin genel kurulun yönetim kurulunun verdiği yetkiye dayanarak sermayesinin \%10'unu aşmamak şartıyla kendi paylarını iktisap ve rehin olarak kabul edebilmesine olanak sağlanmıştır. Öte yandan TTK'nın 520'nci maddesi hükmü uyarınca; şirket, iktisap ettiği kendi payları için iktisap değerlerini karşılayan tutarda yedek akçe ayırır. Bu yedek akçeler, anılan payların devredildikleri veya yok edildikleri takdirde iktisap değerlerini karşılayan tutarda çözülebilirler.

\section{iii. Mevzuatın bilançoya konulmasına ve sermayeye eklenmesine izin verdiği fonlar}

TTK'nın 462'nci maddesinin 3 no.lu fıkrası hükmü uyarınca, bilançoda sermayeye eklenmesine mevzuatın izin verdiği fonların bulunması hâlinde, bu fonlar sermayeye dönüştürülmeden, sermaye taahhüt edilmesi yoluyla sermaye artırılamaz. Hem bu fonların sermayeye dönüştürülmesi hem de aynı zamanda ve aynı oranda sermayenin taahhüt edilmesi yoluyla sermaye artırılabilir. Mevzuatın sermayeye eklenmesine izin verdiği fonlara örnek olarak; kurumlar vergisinden istisna olan gayrimenkul veya iştirak hissesi satış kazancı, enflasyon düzeltmesi sonucu oluşan özsermaye kalemlerine ait enflasyon düzeltme farkları ve vergiye yönelik bazı af kanunları ile bilanço pasifinde özkaynaklar içinde yer alan ve aynı kanunlar ile sermayeye eklenmesine izin verilmiş olan fonları gösterebiliriz. TTK'nın 462/3'üncü maddesiyle getirilen düzenlemeye göre anonim şirketler, bedelsiz sermaye artırımı yapabilecek durumda olmaları halinde, bedelsiz artırıma gitmeden bedelli sermaye artışı yapamayacaklardır. 


\subsection{3. Şarta Bağı ıermaye Artırımı}

TTK ile sermaye artırımında üçüncü bir alternatif olarak "şarta bağlı sermaye artırımı” yöntemi kabul edilmiştir. TTK'nın 463'üncü maddesine göre; genel kurul, yeni çıkarılan tahviller veya benzeri borçlanma araçları nedeniyle, şirkette veya topluluk şirketlerinden alacaklı olanlara veya çalışanlara, esas sözleşmede değiştirme veya alım haklarını kullanmak yoluyla yeni payları edinmek hakkı sağlamak suretiyle, sermayenin şarta bağlanmasına karar verebilir. Şartlı sermaye artırımı, yeni çıkarılacak tahvil ve benzeri borçlanma araçlarının şirketin pay sahiplerine dönüşmelerini amaçlayan, bu yolla şirkete sermaye sağlayan ve çalışanlar için pay senedi çıkarılmasına olanak veren bir sermaye artırımı yöntemidir. Şirket tarafından ihraç edilen tahviller, sahiplerine genellikle önceden saptanmış belirli koşullarla tahvillerin pay senetlerine çevrilmesi hususunda bir seçim hakkı sağlamaktadır. Bu yöntemde, sermayenin artıımının gerçekleşme zamanı üçüncü kişilerin kendilerine tanınan haklarını kullanma kararına, yani şarta bağlı kalmaktadır (http://www.vergimevzuati.org/yeni-ttknagore-anonim-sirketlerde-sermaye-arttirimi/). Şarta bağı sermaye artırımı ile şirketten menkul kıymetler aracılığı ile alacaklı konumda olanların ve çalışanların sermayeye katılmalarına ve dolayısı ile şirket pay sahipleri arasına katılmalarına imkan sağlanmaktadır. Aynı zamanda Anonim Şirketlerin sermaye artırımı sırasında karşılaştığı Genel Kurul'dan onay alma, tescil ve ilan zorunluluğu gibi uzun süreçler azaltılarak işlem kolaylığı sağlanmaktadır (http://yildirimercan.blogspot.com.tr/2013/ 01/anonim-sirketlerde-sarta-bagl-sermaye.html).

Şarta bağlı sermaye artıımına ilişkin düzenlemeye 6102 TTK'nın 463'üncü maddesinde yer verilmiştir. Buna göre, genel kurul, yeni çıkarılan tahviller veya benzeri borçlanma araçlarıyla, şirketten veya topluluk şirketlerinden alacaklı olanlara veya çalışanlara, esas sözleşmede değiştirme veya alım haklarını kullanmak yoluyla yeni payları edinmek hakkı sağlamak suretiyle, sermayenin şarta bağı artııımasına karar verebilir. Şarta bağlı sermaye artııımı yöntemi, yeni çıkarılacak tahvillerin ve benzeri borçlanma araçlarının alacaklılarının şirketin pay sahiplerine dönüşmeleri amaçlanmakta, böylece şirkete sermaye sağlayan, yani finansmana yardımcı olan ve çalışanlar için pay senedi çıkarılmasına imkan veren bir sermaye artırım yöntemidir.

Şarta bağlı sermaye artırımında bulunabilmek için genel kurul kararı gerekmemektedir. Ancak, esas sözleşmede hüküm bulunması ve artırım şartları ile kuralları bu hükümde yer almalıdır. Burada, genel kurul kararı sermayeyi artırmamakta, esas sözleşmede, kanunda sayılmış kişilere değiştirme veya alım haklarını kullanmak yoluyla yeni payları edinmek suretiyle sermayenin şarta bağlı artırılmasına karar verilmektedir. Buna imkan tanıyan ise, esas sözleşme hükmünün kabul edilmesidir (Kendigelen, 2012, 364). Şarta bağlı sermaye artırımı yoluyla pay sahiplerine zarar verilebilir. Bunu önlemek için 6102 TTK' nın 466' ncı maddesi ile düzenleme yapılmıştır. Şarta bağlı sermaye artırımı yönteminde pay sahipleri zarara uğrarlar. Bunun nedeni, pay sahiplerinin rüçhan haklarının (ellerindeki hisse senetleri oranında yeni hisse senedi alım hakları) kaldırılmasıdır. Bu durumda da, pay sahipleri yeni pay alamadıkları için şirketteki katılma oranları düşecek, yani sulanacaktır. Işte Kanunun yukarıdaki düzenlemesi ile bu sulanmanın önüne geçilmektedir. Buna teknik tabirle "önerilme hakkı" denilmektedir. Önerilme hakkı, şarta bağlı sermaye artırımında değiştirme veya satım hakkı içeren tahvillerin veya benzeri borçlanma senetlerinin önce pay sahiplerine önerilmesi zorunluluğuna ilişkin yeni bir pay sahipliği hakkıdır. Bu hak şirketin öneride bulunma zorunluluğundan doğmaktadır. Böylece pay sahibi yeni pay alma hakkını korumuş olmaktadır. Tekrardan vurgulayalım ki, bu hak sadece tahvil ve borçlanma senetlerinin değiştirme ve alım hakları içermesi halinde geçerli olacaktır. Ancak, çalışanlara tanınan alım haklarında pay sahipleri önerilme hakkına sahip olmayacaktır. Bu önerilme hakkı sınırsız bir hak olmayıp, haklı sebeplerin varlığında kaldırılabilecek ya da sınırlandırılabilecektir. Haklı sebep nedir sorusunun cevabını kanun tek tek sayarak vermemekte, örnekleme yapmaktadır. Örneğin, gerekçeye göre piyasa şartları gerektiğinde haklı sebep olarak kabul edilmelidir. Bir aracı kurumun tahvillerin tümünü satın alma önerisi yapması halinde pay sahiplerinin önerilme hakkı kaldırılabilmelidir. Haklı sebebin şirketin menfaati açısından değerlendirilmesi ve eşit işlem ve hakların gözetilerek kullanılması yerinde olacaktır. "Şarta bağlı sermaye artııımı için gerekli olan rüçhan ve önerilmeye muhatap olma haklarının kaldırılması veya sınırlandırılmasından dolayı, hiç kimse haklı görülmeyecek bir şekilde yararlandırılamaz veya kayba uğratılamaz" denilerek, pay sahiplerinin korunduğu bir kez daha vurgulanmaktadır. Önerilme hakkının kaldırılarak, belli kişilere haksız yarar sağlanmasına ve böylece ileride bazı kişilerin hakimiyeti ele geçirmesine izin verilmemelidir (http://www.thelira.com/yazar/31/ekrem-oncu/2099).

Sermaye artırım yöntemlerinin daha iyi anlaşılması için aşă̆ıda Tablo 1'de özet halinde verilmiştir;

Tablo 1: Sermaye Artırım Yöntemleri

\begin{tabular}{|l|l|l|}
\hline $\begin{array}{c}\text { 1- } \begin{array}{l}\text { Sermaye Taahhüdü } \\
\text { Yoluyla Artırımı }\end{array} \\
\text { 2- } \quad \text { İç Kaynaklardan (Bedelsiz) Sermaye Artırımı }\end{array}$ & $\begin{array}{l}\text { 3- } \\
\text { Şarta Bağlı Sermaye } \\
\text { Artırımı }\end{array}$ \\
\hline $\begin{array}{l}\text {-Esas Sermaye Sisteminde } \\
\text { Sermaye Artırımı }\end{array}$ & $\begin{array}{l}\text {-Esas sözleşme veya genel kurul kararıyla ayrılmış ve belli bir } \\
\text { amaca özgülenmemiş yedek akçeler } \\
\text {-Kanuni yedek akçelerin serbestçe kullanılabilen kııımları } \\
\text { i. Genel Kanuni Yedek Akçeler } \\
\text { ii. Şirketin İktisap Ettiği Kendi Pay Senetleri İçin Ayrılan Yedek }\end{array}$ & $\begin{array}{l}\text { Yeni çıkarılan tahviller } \\
\text { veya benzeri borçlanma } \\
\text { araçlarıyla, şrketten veya } \\
\text { topluluk şirketlerinden } \\
\text { alacaklı olanlara veya }\end{array}$ \\
\hline
\end{tabular}




\begin{tabular}{|l|l|l|}
\hline & $\begin{array}{l}\text { Akçe ve Yeniden Değerleme Fonları } \\
\text { iii.Mevzuatın bilançoya konulmasına ve sermayeye eklenmesine } \\
\text { izin verdiği fonlar }\end{array}$ & $\begin{array}{l}\text { çalışanlara, esas } \\
\text { sözleşmede değiştirme } \\
\text { veya alım haklarını } \\
\text { kullanmak yoluyla yeni } \\
\text { payları edinmek hakkı } \\
\text { sağlanması }\end{array}$ \\
\hline $\begin{array}{l}\text {-Kayıtlı Sermaye } \\
\text { Sisteminde Sermaye } \\
\text { Artırımı }\end{array}$ & & \\
\hline
\end{tabular}

\section{TÜRK BANKACILIK SEKTÖRÜNDE SERMAYE ARTIRIMININ INCELENMESI}

Türk finansal sisteminin temeli olan bankacılık sektörü, özellikle son yıllarda meydana finansal liberalleşme sonucunda yeniden yapılanma sürecine girmiş, ancak söz konusu sürece ülkenin ekonomik altyapı sorunlarına çözüm bulunmadan ve çok hızı bir şekilde dahil olunması nedeniyle yüksek maliyetli bankacılık krizleri yaşanmıştır. Ekonomik büyümenin istikrarlı bir şekilde gerçekleşmesi için bankacılık sektörünün sermaye ve kaynaklarıın etkin bir şekilde kullanımına, sağlıklı ve gelişmiş bir finans sektörünün varlığına ihtiyaç duyulmaktadır. Finansal sistemde bir veya birkaç bankanın ödeme güçlüğüne düşmesi, performanslarında yaşanan gerilemeler, sektöre duyulan güveni azaltmaktadır. Banka krizlerine maruz kalındığında, bu krizlerin yol açtığı sorunların çözümlenmesi ve tekrar meydana gelmemesi için bazı önlemler alınmaktadır. Bu önlemlerin başında ise düzgün bir bankacılık sistemi için gerekli altyapının ve hukuki düzenlemelerin oluşturulması, etkin bir denetim-gözetim mekanizmasının kurulması ve sektörün performans, kârıılı̆ının ve sermaye yapısının sürekli izlenmesi gelmektedir (Arıçelik, 2010, s. 97).

Bu bağlamda çalışmada, BiST’te faaliyet gösteren bankaların sermaye artırımlarının hangi şekilde ve hangi düzeyde olduğunu ortaya konması amaçlanmıştır. Diğer bir ifadeyle, bankacılık sektöründe halka arz yoluyla faaliyet gösteren 13 bankanın 2010-2015 yıllara ait finansal verileri incelenerek bankaların sermeye yapıları ve sermaye artırımında uyguladıkları yöntemler tespit edilmeye çalışılmıştır. Araştırmanın verileri 2010-2015 yıllarında sürekli bir şekilde BisT'te faaliyet gösteren bankaların finansal tablolarından elde edilmiştir BiST'te faaliyet gösteren 14 bankanın Kamuyu Aydınlatma Platformuna (KAP) sundukları finansal tablolarından elde edilen verileri analiz edilmiştir. Analize dahil edilen şirketlerin finansal tablolarında hesaplayıp raporlamış oldukları sersmaye yapısını oluşturan faktörleri ve sermaye artırım düzeylerini araştırmak için yapılan bu çalışmada, içerik analizi yöntemi kullanılmıştır. İçerik analizinde yapılan işlem, birbirine benzeyen verilerin belirlenmiş kavramlar kapsamında bir araya getirilmesi ve bunların anlaşabilecek bir biçimde organize edilerek yorumlanması olarak tanımlanmaktadır (Yıldırım ve Şimşek, 2006: 157). Araştırmaya dahil edilen bankaların seçilme nedeni ise, BiST faaliyet göstermeleri ve halka arz olmalarından dolayı Türk bankacılık sektöründe önemli bir yere sahip olmaları ve finansal verilerini yayınlamak zorunda olmalarıdır. Gerekli verileri toplamak amacıyla, öncelikle araştırma kapsamındaki tüm işletmelerin şirketlerin ilgili finansal tabloları KAP'ın internet sitesi olan www.kap.gov.tr adresinden ulaşılmış ve bu veriler doğrultusunda içerik analizi yapılmıştır. Analize dahil edilen bankaların isimleri aşağıda Tablo 2'de gösterilmiştir.

Tablo 2: Araştırmaya Dahil Edilen Bankalar

\begin{tabular}{|cl|}
\hline$\bullet$ & Akbank T.A.Ş \\
\hline$\bullet$ & Alternatifbank A.Ş. \\
\hline$\bullet$ & Albaraka Türk Katıım Bankası A.Ş. \\
\hline$\bullet$ & Finansbank A.Ş. \\
\hline$\bullet$ & Garanti Bankası A.Ş. \\
\hline$\bullet$ & Türkiye Halk Bankası A.Ş. \\
\hline$\bullet$ & Türkiye İş Bankası A.Ş. \\
\hline$\bullet$ & Şekerbank Türk A.Ş. \\
\hline$\bullet$ & Tekstil Bankası A.Ş. \\
\hline$\bullet$ & Türkiye Sınai Kalkınma Bankası A.Ş. \\
\hline$\bullet$ & Türk Ekonomi Bankası A.Ş. \\
\hline$\bullet$ & Türkiye Vakıflar Bankası Türk A.Ş. \\
\hline$\bullet$ & Yapı ve Kredi Bankası A.Ş. \\
\hline
\end{tabular}

\subsection{Akbank T.A.Ş.}

Akbank T.A.Ş.'nin 2010 yılı bilançosu incelendiğinde, şirketin özsermaye toplamı 17.947.594.000 TL olup bu tutarın 3.000.000.000 TL'lik kısmı ödenmiş sermayeden, 6.312.226.000 TL'lik kısmı kar yedeklerinden,4.551.136.000 TL'lik kısmı sermaye yedeklerinden, 3.071.298.000 TL'lik kısmı kar veya zarar hesabından hesabından 12.934.000 TL'lik kısmı ise azınlık 
paylarından oluşmaktadır. Ana Ortaklık Banka 5.000.000.000 TL kayıtlı sermaye tavanı içerisinde tamamı ödenmiş 3.000.000.000 TL'lik sermayesini, 482.691.000 TL'si olağanüstü yedeklerden, 16.554.000 TL'si iştirak satış kârlarından, 755.000 TL'si gayrimenkul satış kârlarından, 500.000.000 TL'si diğer sermaye yedeklerinde yer alan sermaye enflasyon düzeltme farkından karşılanmak üzere toplam 1.000.000.000 TL artırarak 4.000.000.000 TL'ye yükseltmiştir.

Akbank T.A.Ş.'nin 2011 yılı bilançosu incelendiğinde, şirketin özsermaye toplamı 18.131.379.000 TL olup bu tutarın 4.000.000.000 TL'lik kısmı ödenmiş sermayeden, 8.728.740.000 TL'lik kısmı kar yedeklerinden, 2.647.663.000 TL'lik kısmı sermaye yedeklerinden, 2.745.214.000 TL'lik kısmı kar veya zarar hesabından hesabından 9.762.000 TL'lik kısmı ise azınlık paylarından oluşmaktadır. 2011 faaliyet döneminde, şirketin ödenmiş sermayesi 4.000.000.000 TL olup şirket bu faaliyet döneminde herhangi bir sermaye artışına gitmemiştir.

Akbank T.A.Ş.'nin 2012 yılı bilançosu incelendiğinde, şirketin özsermaye toplamı 22.475.768.000 TL olup bu tutarın 4.000.000.000 TL'lik kısmı ödenmiş sermayeden, 10.572.393.000 TL'lik kısmı kar yedeklerinden, 4.554.128.000 TL'lik kısmı sermaye yedeklerinden , 3.349.174.000 TL'lik kısmı kar veya zarar hesabından hesabından 73.000 TL'lik kısmı ise azınlık paylarından oluşmaktadır. 2012 faaliyet döneminde, şirketin ödenmiş sermayesi 4.000.000.000 TL olup şirket bu faaliyet döneminde herhangi bir sermaye artışına gitmemiştir.

Akbank T.A.Ş.'nin 2013 yılı bilançosu incelendiğinde, şirketin özsermaye toplamı 22.134.979.000 TL olup bu tutarın 4.000.000.000 TL'lik kısmı ödenmiş sermayeden, 13.333.443.000 TL'lik kısmı kar yedeklerinden, 1.515.053.000 TL'lik kısmı sermaye yedeklerinden, 3.286.398.000 TL'lik kısmı kar veya zarar hesabından hesabından 85.000 TL'lik kısmı ise azınlık paylarından oluşmaktadır. 2013 faaliyet döneminde, şirketin ödenmiş sermayesi 4.000.000.000 TL olup şirket bu faaliyet döneminde herhangi bir sermaye artışına gitmemiştir.

Akbank T.A.Ş.'nin 2014 yılı bilançosu incelendiğinde, şirketin özsermaye toplamı 25.111.826.000 TL olup bu tutarın 4.000.000.000 TL'lik kısmı ödenmiş sermayeden, 15.845.847.000 TL'lik kısmı kar yedeklerinden, 2.781.626.000 TL'lik kısmı sermaye yedeklerinden, 3.159.678.000 TL'lik kısmı kar veya zarar hesabından hesabından 100.000 TL'lik kısmı ise azınlık paylarından oluşmaktadır. 2014 faaliyet döneminde, şirketin ödenmiş sermayesi 4.000.000.000 TL olup şirket bu faaliyet döneminde herhangi bir sermaye artışına gitmemiştir.

Akbank T.A.Ş.'nin 2015 yılı bilançosu incelendiğinde, şirketin özsermaye toplamı 26.689.177.000 TL olup bu tutarın 4.000.000.000 TL'lik kısmı ödenmiş sermayeden, 17.766.503.000 TL'lik kısmı kar yedeklerinden, 1.927.826.000 TL'lik kısmı sermaye yedeklerinden, 2.994.848.000 TL'lik kısmı kar veya zarar hesabından hesabından 100.000 TL'lik kısmı ise azınlık paylarından oluşmaktadır. 2015 faaliyet döneminde, şirketin ödenmiş sermayesi 4.000.000.000 TL olup şirket bu faaliyet döneminde herhangi bir sermaye artışına gitmemiştir.

Genel olarak, Akbank T.A.Ş.'nin 2010-2015 dönemlerine ilişkin finansal verileri bir bütün olarak değerlendirildiğinde, şirketin 2010 faaliyet döneminde iç kaynaklardan sermaye artırımına gittiği, 2011-2015 faaliyet dönemlerinde ise herhangi bir sermaye artırımına gitmediği anlaşılmıştır. Ayrıca banka faaliyetlerini yüksek kârlılıkla sürdürmekte ve dönem kârlarının büyük bölümünü sermaye artırımı veya yedeklere aktarım şeklinde özkaynaklar içinde muhafaza etmektedir. Öte yandan Banka'nın özkaynaklarının çok küçük bir bölümü sabit kıymet ve iştirakler gibi sabit yatırımlara yönlendirilmiş olup Banka'nın serbest özsermayesi oldukça yüksektir ve likit ile getirili aktiflerde değerlendirilmektedir. Tüm bu hususlar dikkate alındığında Banka faaliyetlerine yüksek özkaynak gücü olduğu söylenebilir.

\subsection{Alternatifbank A.S.}

Alternatifbank A.Ş.'nin 2010 yılı bilançosu incelendiğinde, şirketin özsermaye toplamı 462.383 .000 TL olup bu tutarın 300.000.000 TL'lik kısmı ödenmiş sermayeden, -447.000 TL'lik kısmı sermaye yedeklerinden, 129.860.000 TL'lik kısmı kar yedeklerinden, 32.970.000 TL'lik kısmı kar veya zarar hesabından oluşmaktadır. 2010 faaliyet döneminde, şirketin ödenmiş sermayesi 300.000.000 TL olup şirket bu faaliyet döneminde herhangi bir sermaye artışına gitmemiştir.

Alternatifbank A.Ş.'nin 2011 yılı bilançosu incelendiğinde, şirketin özsermaye toplamı 484.732 .000 TL olup bu tutarın 300.000.000 TL'lik kısmı ödenmiş sermayeden, -6.361.000 TL'lik kısmı sermaye yedeklerinden, 157.448.000 TL'lik kısmı kar yedeklerinden, 33.645.000 TL'lik kısmı kar veya zarar hesabından oluşmaktadır. 2011 faaliyet döneminde, şirketin ödenmiş sermayesi 300.000.000 TL olup şirket bu faaliyet döneminde herhangi bir sermaye artışına gitmemiştir.

Alternatifbank A.Ş.'nin 2012 yılı bilançosu incelendiğinde, şirketin özsermaye toplamı 590.674.000 TL olup bu tutarın 420.000.000 TL'lik kısmı ödenmiş sermayeden, 10.037.000 TL'lik kısmı sermaye yedeklerinden, 89.428.000 TL'lik kısmı kar yedeklerinden, 55.378.000 TL'lik kısmı kar veya zarar hesabından, 15.831 .000 TL'lik kısmı ise azınlık paylarından oluşmaktadır. 2011 faaliyet döneminde, şirketin ödenmiş sermayesi 120.000.000 TL artırılmış olup, 114.618.000 TL olağanüstü yedek akçelerden, 5.382.000 TL geçmiş dönem karından sağlanmıştır.

Alternatifbank A.Ş.'nin 2013 yılı bilançosu incelendiğinde, şirketin özsermaye toplamı 594.827.000 TL olup bu tutarın 420.000.000 TL'lik kısmı ödenmiş sermayeden, -41.066.000 TL'lik kısmı sermaye yedeklerinden, 122.652.000 TL'lik kısmı kar 
yedeklerinden, 93.241.000 TL'lik kısmı kar veya zarar hesabından oluşmaktadır. 2013 faaliyet döneminde, şirketin ödenmiş sermayesi 420.000.000 TL olup şirket bu faaliyet döneminde herhangi bir sermaye artışına gitmemiştir.

Alternatifbank A.Ş.'nin 2014 yılı bilançosu incelendiğinde, şirketin özsermaye toplamı 959.457.000 TL olup bu tutarın 620.000.000 TL'lik kısmı ödenmiş sermayeden, -6.500.000 TL'lik kısmı sermaye yedeklerinden, 215.420.000 TL'lik kısmı kar yedeklerinden, 130.537.000 TL'lik kısmı kar veya zarar hesabından oluşmaktadır. 2014 faaliyet döneminde, şirketin ödenmiş sermayesi 620.000.000 TL olup şirket bu faaliyet döneminde herhangi bir sermaye artışına gitmemiştir.

Alternatifbank A.Ş.'nin 2015 yılı bilançosu incelendiğinde, şirketin özsermaye toplamı 996.610.000TL olup bu tutarın 620.000.000 TL'lik kısmı ödenmiş sermayeden, -28.858.000 TL'lik kısmı sermaye yedeklerinden, 339.861.000 TL'lik kısmı kar yedeklerinden, 65.607.000 TL'lik kısmı kar veya zarar hesabından oluşmaktadır. 2014 faaliyet döneminde, şirketin ödenmiş sermayesi 620.000.000 TL olup şirket bu faaliyet döneminde herhangi bir sermaye artışına gitmemiştir.

Genel olarak, Alternatifbank A.Ş.'nin 2010-2015 dönemlerine ilişkin finansal verileri bir bütün olarak değerlendirildiğinde, şirketin 2010, 2011, 2013, 2014 ve 2015 faaliyet dönemlerinde herhangi bir sermaye artırımına gitmediği, 2012 faaliyet döneminde ise iç kaynaklardan sermaye artırımına gittiği anlaşılmıştır. Ayrıca banka faaliyetlerini yüksek kârlııkla sürdürmekte ve dönem kârlarının büyük bölümünü sermaye artırımı veya yedeklere aktarım şeklinde özkaynaklar içinde muhafaza etmektedir. Öte yandan Banka'nın özkaynaklarının çok küçük bir bölümü sabit kıymet ve iştirakler gibi sabit yatırımlara yönlendirilmiş olup Banka'nın serbest özsermayesi oldukça yüksektir ve likit ile getirili aktiflerde değerlendirilmektedir. Tüm bu hususlar dikkate alındığında Banka faaliyetlerine yüksek özkaynak gücü olduğu söylenebilir.

\subsection{Albaraka Türk Katılım Bankası A.Ş.}

Albaraka Türk Katılım Bankası A.Ş.'nin 2010 yılı bilançosu incelendiğinde, şirketin özsermaye toplamı 852.635.000 TL olup bu tutarın 539.000.000 TL'lik kısmı ödenmiş sermayeden, 31.109.000 TL'lik kısmı sermaye yedeklerinden, 148.147.000 TL'lik kısmı kar yedeklerinden, 134.379.000 TL'lik kısmı kar veya zarar hesabından hesabından oluşmaktadır. 2010 faaliyet döneminde, şirketin ödenmiş sermayesi 539.000.000 TL olup şirket bu faaliyet döneminde herhangi bir sermaye artışına gitmemiştir.

Albaraka Türk Katılım Bankası A.Ş.'nin 2011 yılı bilançosu incelendiğinde, şirketin özsermaye toplamı 1.004.251.000 TL olup bu tutarın 539.000.000 TL'lik kısmı ödenmiş sermayeden, 35.330.000 TL'lik kısmı sermaye yedeklerinden, 269.051.000 TL'lik kısmı kar yedeklerinden, 160.870.000 TL'lik kısmı kar veya zarar hesabından oluşmaktadır. 2011 faaliyet döneminde, şirketin ödenmiş sermayesi 539.000.000 TL olup şirket bu faaliyet döneminde herhangi bir sermaye artışına gitmemiştir.

Albaraka Türk Katılım Bankası A.Ş.'nin 2012 yılı bilançosu incelendiğinde, şirketin özsermaye toplamı 1.218.333.000 TL olup bu tutarın 900.000.000 TL'lik kısmı ödenmiş sermayeden, 56.687.000 TL'lik kısmı sermaye yedeklerinden, 68.920.000 TL'lik kısmı kar yedeklerinden, 192.726.000 TL'lik kısmı kar veya zarar hesabından oluşmaktadır. İşletme 2012 faaliyet dönemi içerisinde iç kaynaklardan 361.000.000 TL sermaye artırımına gitmiştir. Sermaye artıımının tamamı olağanüstü yedek akçelerden karşılanmıştır.

Albaraka Türk Katılım Bankası A.Ş.'nin 2013 yılı bilançosu incelendiğinde, şirketin özsermaye toplamı 1.497.268.000 TL olup bu tutarın 900.000.000 TL'lik kısmı ödenmiş sermayeden, 92.780.000 TL'lik kısmı sermaye yedeklerinden, 261.645.000 TL'lik kısmı kar yedeklerinden, 242.843.000 TL'lik kısmı kar veya zarar hesabından oluşmaktadır. 2013 faaliyet döneminde, şirketin ödenmiş sermayesi 900.000.000 TL olup şirket bu faaliyet döneminde herhangi bir sermaye artışına gitmemiştir.

Albaraka Türk Katılım Bankası A.Ş.'nin 2014 yılı bilançosu incelendiğinde, şirketin özsermaye toplamı 1.790.927.000 TL olup bu tutarın 900.000.000 TL'lik kısmı ödenmiş sermayeden, 160.196.000 TL'lik kısmı sermaye yedeklerinden, 470.272.000 TL'lik kısmı kar yedeklerinden, 260.594.000 TL'lik kısmı kar veya zarar hesabından oluşmaktadır. 2013 faaliyet döneminde, şirketin ödenmiş sermayesi 900.000.000 TL olup şirket bu faaliyet döneminde herhangi bir sermaye artışına gitmemiştir.

Albaraka Türk Katılım Bankası A.Ş.'nin 2015 yılı bilançosu incelendiğinde, şirketin özsermaye toplamı 2.103.914.000 TL olup bu tutarın 900.000.000 TL'lik kısmı ödenmiş sermayeden, 200.910.000 TL'lik kısmı sermaye yedeklerinden, 696.531.000 TL'lik kısmı kar yedeklerinden, 306.473.000 TL'lik kısmı kar veya zarar hesabından oluşmaktadır. 2013 faaliyet döneminde, şirketin ödenmiş sermayesi 900.000.000 TL olup şirket bu faaliyet döneminde herhangi bir sermaye artışına gitmemiştir.

Bu çerçevede, Albaraka Türk Katılım Bankası A.Ş.'nin 2010-2015 dönemlerine ilişkin finansal verileri bir bütün olarak değerlendirildiğinde, şirketin 2010, 2011, 2013, 2014 ve 2015 faaliyet döneminde herhangi bir sermaye artırımına gitmediği, 2012 faaliyet döneminde iç kaynaklardan sermaye artırımında bulunduğu saptanmıştır. Ayrıca Banka, faaliyetlerini karlııkla sürdürmekte ve dönem karlarının büyük bölümünü sermaye artıımı veya yedeklere aktarım şeklinde özkaynaklar içinde muhafaza etmektedir. Öte yandan Banka'nın özkaynakları likit ve getirili aktiflerde değerlendirilmektedir. 


\subsection{Finansbank A.Ş.}

Finansbank A.Ş.' nin 2010 yılı bilançosu incelendiğinde, şirketin özsermaye toplamı 5.386.467.000 TL olup bu tutarın 2.205.000.000 TL'lik kısmı ödenmiş sermayeden, 1.996.424.000 TL'lik kısmı kar yedeklerinden, 103.735.000 TL'lik kısmı sermaye yedeklerinden, 937.603.000 TL'lik kısmı kar veya zarar hesabından, 143.705.000 TL'lik kısmı ise azınlık paylarından oluşmaktadır. 2010 yılına ilişkin özkaynak değişim tablosunda yer alan 630.000.000 TL sermaye artırımının 547.143.000 TL'si nakit, 82.857.000 TL'si olağanüsütü yedeklerden karşılanmıştır.

Finansbank A.Ş.'nin 2011 yılı bilançosu incelendiğinde, şirketin özsermaye toplamı 5.911.323.000 TL olup bu tutarın 2.440.000.000 TL'lik kısmı ödenmiş sermayeden, 2.672.370.000 TL'lik kısmı kar yedeklerinden, -259.363.000 TL'lik kısmı sermaye yedeklerinden, 898.412.000 TL'lik kısmı kar veya zarar hesabından, 159.904.000 TL'lik kısmı ise azınlık paylarından oluşmaktadır. 2011 yılına ilişkin özkaynak değişim tablosunda yer alan 235.000.000 TL sermaye artırımının 116.333.000 TL'si nakit, 118.667.000 TL'si olağanüstü yedeklerden karşılanmıştır.

Finansbank A.Ş.' nin 2012 yılı bilançosu incelendiğinde, şirketin özsermaye toplamı 7.448.584.000 TL olup bu tutarın 2.565.000.000 TL'lik kısmı ödenmiş sermayeden, 3.394.920.000 TL'lik kısmı kar yedeklerinden, 187.243.000 TL'lik kısmı sermaye yedeklerinden, 1.151.659.000 TL'lik kısmı kar veya zarar hesabından, 149.762.000 TL'lik kısmı ise azınlık paylarından oluşmaktadır. 2012 yılına ilişkin özkaynak değişim tablosunda yer alan 125.000.000 TL sermaye artırımının tamamı olağanüstü yedeklerden karşılanmıştır.

Finansbank A.Ş.'nin 2013 yılı bilançosu incelendiğinde, şirketin özsermaye toplamı 7.648.478.000 TL olup bu tutarın 2.700.000.000 TL'lik kısmı ödenmiş sermayeden, 4.002.628.000 TL'lik kısmı kar yedeklerinden, 211.611.000 TL'lik kısmı sermaye yedeklerinden, 734.239.000 TL'lik kısmı kar veya zarar hesabından oluşmaktadır. 2013 yılına ilişkin özkaynak değişim tablosunda yer alan 135.000.000 TL sermaye artırımının tamamı olağanüstü yedeklerden karşılanmıştır.

Finansbank A.Ş.'nin 2014 yılı bilançosu incelendiğinde, şirketin özsermaye toplamı 8.574.148.000 TL olup bu tutarın 2.835.000.000 TL'lik kısmı ödenmiş sermayeden, 4.601.867.000 TL'lik kısmı kar yedeklerinden, 259.853.000 TL'lik kısmı sermaye yedeklerinden, 877.428.000 TL'lik kısmı kar veya zarar hesabından oluşmaktadır. Ayrıca şirket bu faaliyet döneminde herhangi bir sermaye artışına gitmemiştir.

Finansbank A.Ş.'nin 2015 yılı bilançosu incelendiğinde, şirketin özsermaye toplamı 9.023.776.000 TL olup bu tutarın 3.000.000.000 TL'lik kısmı ödenmiş sermayeden, 5.314.295.000TL'lik kısmı kar yedeklerinden, 3.709.000 TL'lik kısmı sermaye yedeklerinden, 705.772.000 TL'lik kısmı kar veya zarar hesabından oluşmaktadır. Ayrıca şirket bu faaliyet döneminde herhangi bir sermaye artışına gitmemiştir.

Bu çerçevede, Finansbank A.Ş.'nin 2010-2015 dönemlerine ilişkin finansal verileri bir bütün olarak değerlendirildiğinde, şirketin 2010, 2011 ve 2015 faaliyet dönemlerinde hem iç kaynaklardan hem dış kaynaklardan, 2012, 2013 faaliyet dönemlerinde yalnızca iç kaynaklardan sermaye artırımında bulunduğu ve 2014 ve 2015 faaliyet dönemlerinde ise sermaye artırımında bulunmadığı saptanmıştır.

\subsection{Garanti Bankası A.Ş.}

Garanti Bankası A.Ş.' nin 2010 yılı bilançosu incelendiğinde, şirketin özsermaye toplamı 16.718.254.000 TL olup bu tutarın 4.200.000.000 TL'lik kısmı ödenmiş sermayeden, 2.954.777.000 TL'lik kısmı sermaye yedeklerinden, 6.084.980.000 TL'lik kısmı kar yedeklerinden, 3.381.114.000 TL'lik kısmı kar veya zarar hesabından, 97.383.000 TL'lik kısmı ise azınlık paylarından oluşmaktadır. 2010 faaliyet döneminde, şirketin ödenmiş sermayesi 4.200 .000 .000 TL olup şirket bu faaliyet döneminde herhangi bir sermaye artışına gitmemiştir.

Garanti Bankası A.Ş.' nin 2011 yılı bilançosu incelendiğinde, şirketin özsermaye toplamı 17.899.787.000 TL olup bu tutarın 4.198.641.000 TL'lik kısmı ödenmiş sermayeden, 1.421.521.000 TL'lik kısmı sermaye yedeklerinden, 8.840.819.000 TL'lik kısmı kar yedeklerinden, 3.326.299.000 TL'lik kısmı kar veya zarar hesabından, 112.527 .000 TL'lik kısmı ise azınlık paylarından oluşmaktadır. 2011 faaliyet döneminde, şirketin ödenmiş sermayesi 4.198.641.000 TL olup şirket bu faaliyet döneminde herhangi bir sermaye artışına gitmemiştir.

Garanti Bankası A.Ş.'nin 2012 yılı bilançosu incelendiğinde, şirketin özsermaye toplamı 21.656.946.000 TL olup bu tutarın 4.196.934.000 TL'lik kısmı ödenmiş sermayeden, 2.588.089.000 TL'lik kısmı sermaye yedeklerinden, 11.397.319.000 TL'lik kısmı kar yedeklerinden, 3.334.080.000 TL'lik kısmı kar veya zarar hesabından, 140.524.000 TL'lik kısmı ise azınlık paylarından oluşmaktadır. 2012 faaliyet döneminde, şirketin ödenmiş sermayesi 4.196.934.000 TL olup şirket bu faaliyet döneminde herhangi bir sermaye artışına gitmemiştir.

Garanti Bankası A.Ş.'nin 2013 yılı bilançosu incelendiğinde, şirketin özsermaye toplamı 22.584.984.000 TL olup bu tutarın 4.200.000.000 TL'lik kısmı ödenmiş sermayeden, 1.848.185.000 TL'lik kısmı sermaye yedeklerinden, 13.531.239.000 TL'lik kısmı kar yedeklerinden, 3.005.560.000 TL'lik kısmı kar veya zarar hesabından, 162.818.000 TL'lik kısmı ise azınlık 
paylarından oluşmaktadır. 2013 faaliyet döneminde, şirketin ödenmiş sermayesi 4.200.000.000 TL olup şirket bu faaliyet döneminde herhangi bir sermaye artışına gitmemiştir.

Garanti Bankası A.Ş.' nin 2014 yılı bilançosu incelendiğinde, şirketin özsermaye toplamı 26.613.138.000 TL olup bu tutarın 4.200.000.000 TL'lik kısmı ödenmiş sermayeden, 1.364.822.000 TL'lik kısmı sermaye yedeklerinden, 17.374.205.000 TL'lik kısmı kar yedeklerinden, 3.674.111.000 TL'lik kısmı kar veya zarar hesabından, 162.818.000 TL'lik kısmı ise azınlık paylarından oluşmaktadır. 2014 faaliyet döneminde, şirketin ödenmiş sermayesi 4.200.000.000 TL olup şirket bu faaliyet döneminde herhangi bir sermaye artışına gitmemiştir.

Garanti Bankası A.Ş.' nin 2015 yılı bilançosu incelendiğinde, şirketin özsermaye toplamı 30.981.055.000 TL olup bu tutarın 4.200.000.000 TL'lik kısmı ödenmiş sermayeden, 2.870.616.000 TL'lik kısmı sermaye yedeklerinden, 20.503.932.000 TL'lik kısmı kar yedeklerinden, 3.406.507.000 TL'lik kısmı kar veya zarar hesabından oluşmaktadır. 2014 faaliyet döneminde, şirketin ödenmiş sermayesi 4.200.000.000 TL olup şirket bu faaliyet döneminde herhangi bir sermaye artışına gitmemiştir.

Bu çerçevede, Garanti Bankası A.Ş.'nin 2010-2015 dönemlerine ilişkin finansal verileri bir bütün olarak değerlendirildiğinde, şirketin ilgili faaliyet dönemlerinde herhangi bir sermaye artırımına gitmediği anlaşılmıştır.

\subsection{Türkiye Halk Bankası A.Ş.}

Türkiye Halk Bankası A.Ş.'nin 2010 yılı bilançosu incelendiğinde, şirketin özsermaye toplamı 7.372.325.000 TL olup bu tutarın 1.250.000.000 TL'lik kısmı ödenmiş sermayeden, 1.334.042.000 TL'lik kısmı sermaye yedeklerinden, 2.893.106.000 TL'lik kısmı kar yedeklerinden, 1.888.693.000 TL'lik kısmı kar veya zarar hesabından, 6.484.000 TL'lik kısmı ise azınlık paylarından oluşmaktadır. 2010 faaliyet döneminde, şirketin ödenmiş sermayesi 1.250.000.000 TL olup şirket bu faaliyet döneminde herhangi bir sermaye artışına gitmemiştir.

Türkiye Halk Bankası A.Ş.' nin 2011 yılı bilançosu incelendiğinde, şirketin özsermaye toplamı 8.560.870.000 TL olup bu tutarın 1.250.000.000 TL'lik kısmı ödenmiş sermayeden, 942.479.000 TL'lik kısmı sermaye yedeklerinden, 4.280.068.000 TL'lik kısmı kar yedeklerinden, 2.081.483.000 TL'lik kısmı kar veya zarar hesabından, 6.840.000 TL'lik kısmı ise azınlık paylarından oluşmaktadır. 2011 faaliyet döneminde, şirketin ödenmiş sermayesi 1.250.000.000 TL olup şirket bu faaliyet döneminde herhangi bir sermaye artışına gitmemiştir.

Türkiye Halk Bankası A.Ş.'nin 2012 yılı bilançosu incelendiğinde, şirketin özsermaye toplamı 11.500.256.000 TL olup bu tutarın 1.250.000.000 TL'lik kısmı ödenmiş sermayeden, 1.627.545.000 TL'lik kısmı sermaye yedeklerinden, 5.939.622.000 TL'lik kısmı kar yedeklerinden, 2.678.327.000 TL'lik kısmı kar veya zarar hesabından, 4.762.000 TL'lik kısmı ise azınlık paylarından oluşmaktadır. 2012 faaliyet döneminde, şirketin ödenmiş sermayesi 1.250.000.000 TL olup şirket bu faaliyet döneminde herhangi bir sermaye artışına gitmemiştir.

Türkiye Halk Bankası A.Ş.' nin 2013 yılı bilançosu incelendiğinde, şirketin özsermaye toplamı 14.145.773.000 TL olup bu tutarın 1.250.000.000 TL'lik kısmı ödenmiş sermayeden, 2.040.918.000 TL'lik kısmı sermaye yedeklerinden, 8.104.012.000 TL'lik kısmı kar yedeklerinden, 2.750.843.000 TL'lik kısmı kar veya zarar hesabından, 1.990 .000 TL'lik kısmı ise azınlık paylarından oluşmaktadır. 2013 faaliyet döneminde, şirketin ödenmiş sermayesi 1.250.000.000 TL olup şirket bu faaliyet döneminde herhangi bir sermaye artışına gitmemiştir.

Türkiye Halk Bankası A.Ş.' nin 2014 yılı bilançosu incelendiğinde, şirketin özsermaye toplamı 16.535.922.000 TL olup bu tutarın 1.250.000.000 TL'lik kısmı ödenmiş sermayeden, 2.528.604.000 TL'lik kısmı sermaye yedeklerinden, 10.551.550.000 TL'lik kısmı kar yedeklerinden, 2.205.768.000 TL'lik kısmı kar veya zarar hesabından, 1.990 .000 TL'lik kısmı ise azınlık paylarından oluşmaktadır. 2014 faaliyet döneminde, şirketin ödenmiş sermayesi 1.250 .000 .000 TL olup şirket bu faaliyet döneminde herhangi bir sermaye artışına gitmemiştir.

Türkiye Halk Bankası A.Ş.' nin 2015 yılı bilançosu incelendiğinde, şirketin özsermaye toplamı 19.424.343.000 TL olup bu tutarın 1.250.000.000 TL'lik kısmı ödenmiş sermayeden, 3.309.143.000 TL'lik kısmı sermaye yedeklerinden, 12.549.887.000 TL'lik kısmı kar yedeklerinden, 2.315.313.000 TL'lik kısmı kar veya zarar hesabından oluşmaktadır. 2015 faaliyet döneminde, şirketin ödenmiş sermayesi 1.250.000.000 TL olup şirket bu faaliyet döneminde herhangi bir sermaye artışına gitmemiştir.

Bu çerçevede, Türkiye Halk Bankası A.Ş.'nin 2010-2015 dönemlerine ilişkin finansal verileri bir bütün olarak değerlendirildiğinde, şirketin ilgili faaliyet dönemlerinde herhangi bir sermaye artırımına gitmediği tespit edilmiştir.

\subsection{Türkiye İş Bankası A.Ş.}

Türkiye İş Bankası A.Ş.' nin 2010 yılı bilançosu incelendiğinde, şirketin özsermaye toplamı 18.986.655.000 TL olup bu tutarın 4.500.000.000 TL'lik kısmı ödenmiş sermayeden, 2.890.175.000 TL'lik kısmı sermaye yedeklerinden, 5.198.120.000 TL'lik kısmı kar yedeklerinden, 3.028.597.000 TL'lik kısmı kar veya zarar hesabından, 2.649.763.000 TL'lik kısmı ise azınlık 
paylarından oluşmaktadır. 2010 yılına ilişkin özkaynak değişim tablosunda yer alan 1.420.361.000 TL sermaye artırımının 1.057.425.000 TL'si kar yedeklerinden, 362.936.000 TL'si sermaye yedeklerden karşılanmıştır.

Türkiye İş Bankası A.Ş.' nin 2011 yılı bilançosu incelendiğinde, şirketin özsermaye toplamı 20.310.569.000 TL olup bu tutarın 4.500.000.000 TL'lik kısmı ödenmiş sermayeden, 2.808.602.000 TL'lik kısmı sermaye yedeklerinden, 8.352.002.000 TL'lik kısmı kar yedeklerinden, 2.179.515.000 TL'lik kısmı kar veya zarar hesabından, 2.470.450.000 TL'lik kısmı ise azınlık paylarından oluşmaktadır. 2011 faaliyet döneminde, şirketin ödenmiş sermayesi 4.500.000.000 TL olup şirket bu faaliyet döneminde herhangi bir sermaye artışına gitmemiştir.

Türkiye İş Bankası A.Ş.'nin 2012 yılı bilançosu incelendiğinde, şirketin özsermaye toplamı 24.858.755.000 TL olup bu tutarın 4.500.000.000 TL'lik kısmı ödenmiş sermayeden, 4.261.752.000 TL'lik kısmı sermaye yedeklerinden, 10.402.674.000 TL'lik kısmı kar yedeklerinden, 2.802.512.000 TL'lik kısmı kar veya zarar hesabından, 2.891.817.000 TL'lik kısmı ise azınlık paylarından oluşmaktadır. 2012 faaliyet döneminde, şirketin ödenmiş sermayesi 4.500.000.000 TL olup şirket bu faaliyet döneminde herhangi bir sermaye artışına gitmemiştir.

Türkiye İ̧̧ Bankası A.Ş.' nin 2013 yılı bilançosu incelendiğinde, şirketin özsermaye toplamı 25.894.626.000 TL olup bu tutarın 4.500.000.000 TL'lik kısmı ödenmiş sermayeden, 2.361.992.000 TL'lik kısmı sermaye yedeklerinden, 13.278.022.000 TL'lik kısmı kar yedeklerinden, 2.621.162.000 TL'lik kısmı kar veya zarar hesabından, 3.133.450.000 TL'lik kısmı ise azınlık paylarından oluşmaktadır. 2013 faaliyet döneminde, şirketin ödenmiş sermayesi 4.500.000.000 TL olup şirket bu faaliyet döneminde herhangi bir sermaye artışına gitmemiştir.

Türkiye İş Bankası A.Ş.' nin 2014 yılı bilançosu incelendiğinde, şirketin özsermaye toplamı 31.712.461.000 TL olup bu tutarın 4.500.000.000 TL'lik kısmı ödenmiş sermayeden, 5.078.348.000 TL'lik kısmı sermaye yedeklerinden, 15.925.056.000 TL'lik kısmı kar yedeklerinden, 2.702.910.000 TL'lik kısmı kar veya zarar hesabından, 3.506.147.000 TL'lik kısmı ise azınlık paylarından oluşmaktadır. 2014 faaliyet döneminde, şirketin ödenmiş sermayesi 4.500.000.000 TL olup şirket bu faaliyet döneminde herhangi bir sermaye artışına gitmemiştir.

Türkiye İş Bankası A.Ş.' nin 2015 yılı bilançosu incelendiğinde, şirketin özsermaye toplamı 31.712.461.000 TL olup bu tutarın 4.500.000.000 TL'lik kısmı ödenmiş sermayeden, 6.934.794.000 TL'lik kısmı sermaye yedeklerinden, 17.507.958.000 TL'lik kısmı kar yedeklerinden, 3.092.238.000 TL'lik kısmı kar veya zarar hesabından oluşmaktadır. 2015 faaliyet döneminde, şirketin ödenmiş sermayesi 4.500.000.000 TL olup şirket bu faaliyet döneminde herhangi bir sermaye artışına gitmemiştir.

Bu çerçevede, Türkiye İş Bankası Bankası A.Ş.'nin 2010-2015 dönemlerine ilişkin finansal verileri bir bütün olarak değerlendirildiğinde, şirketin 2010 faaliyet döneminde iç kaynaklardan sermaye artırımında bulunduğu, 2011-2015 faaliyet döneminde ise herhangi bir sermaye artırımına gitmediği tespit edilmiştir.

\section{8. Şekerbank Türk A.Ş.}

Şekerbank Türk A.Ş.' nin 2010 yılı bilançosu incelendiğinde, şirketin özsermaye toplamı 1.400.497.000 TL olup bu tutarın 750.000.000 TL'lik kısmı ödenmiş sermayeden, 66.252.000 TL'lik kısmı sermaye yedeklerinden, 413.276.000 TL'lik kısmı kar yedeklerinden, 170.969.000 TL'lik kısmı kar veya zarar hesabından oluşmaktadır. Cari dönem içinde yapılan sermaye artırımları ve kaynakları ile artıılan sermaye payına ilişkin bilgiler : 28 Haziran 2010 itibarıyla Ana Ortaklık Banka'nın sermayesi 250.000.000 artırılmış olup 162.210.000 TL'si olağanüstü yedeklerden, 59.300.000 TL'si diğer sermaye yedeklerinden, 11.220.000 TL'si iştirak satış karından, 5.270.000 TL'si hisse senedi ihraç primlerinden ve 12.000.000 TL'si Genel Kurul'da onaylanan 2009 yılı karından karşılanmıştır.

Şekerbank Türk A.Ş.' nin 2011 yılı bilançosu incelendiğinde, şirketin özsermaye toplamı 1.462.137.000 TL olup bu tutarın 1.000.000.000 TL'lik kısmı ödenmiş sermayeden, 29.456.000 TL'lik kısmı sermaye yedeklerinden, 314.230.000 TL'lik kısmı kar yedeklerinden, 118.451.000 TL'lik kısmı kar veya zarar hesabından oluşmaktadır. Cari dönem içinde sermaye yedeklerinden sermayeye ilave edilen kısma ilişkin bilgiler: 30 Haziran 2011 tarihi itibarıla Banka ödenmiş sermayesi, 225.000.000 TL olağanüstü yedeklerden, 25.000.000 TL geçmiş dönem karlarından, tamamı iç kaynaklardan karşılanmak üzere 250.000.000 artırılarak 750.000.000 TL'den 1.000.000.000 TL'ye çıkarılmıştır.

Şekerbank Türk A.Ş.' nin 2012 yılı bilançosu incelendiğinde, şirketin özsermaye toplamı 1.824.741.000 TL olup bu tutarın 1.000.000.000 TL'lik kısmı ödenmiş sermayeden, 151.557.000 TL'lik kısmı sermaye yedeklerinden, 432.681.000TL'lik kısmı kar yedeklerinden, 240.503.000 TL'lik kısmı kar veya zarar hesabından oluşmaktadır. 2012 faaliyet döneminde, şirketin ödenmiş sermayesi 1.000.000.000 TL olup şirket bu faaliyet döneminde herhangi bir sermaye artışına gitmemiştir.

Şekerbank Türk A.Ş.' nin 2013 yılı bilançosu incelendiğinde, şirketin özsermaye toplamı 2.055.448.000 TL olup bu tutarın 1.000.000.000 TL'lik kısmı ödenmiş sermayeden, 172.048.000 TL'lik kısmı sermaye yedeklerinden, 673.184.000 TL'lik kısmı kar yedeklerinden, 210.216.000 TL'lik kısmı kar veya zarar hesabından oluşmaktadır. 2013 faaliyet döneminde, şirketin ödenmiş sermayesi 1.000.000.000 TL olup şirket bu faaliyet döneminde herhangi bir sermaye artışına gitmemiştir. 
Şekerbank Türk A.Ş.' nin 2014 yılı bilançosu incelendiğinde, şirketin özsermaye toplamı 2.391.813.000 TL olup bu tutarın 1,087,187,000 TL'lik kısmı ödenmiş sermayeden, 197.193.000 TL'lik kısmı sermaye yedeklerinden, 883.400.000 TL'lik kısmı kar yedeklerinden, 224.033.000 TL'lik kısmı kar veya zarar hesabından oluşmaktadır. 2014 faaliyet döneminde, şirketin ödenmiş sermayesi 1.087.187.000TL olup, şirket 87.187.000 TL'lik sermaye artışına gitmiştir.

Şekerbank Türk A.Ş.' nin 2015 yılı bilançosu incelendiğinde, şirketin özsermaye toplamı 2.526.942.000 TL olup bu tutarın 1.158.000.000 TL'lik kısmı ödenmiş sermayeden, 171.370.000 TL'lik kısmı sermaye yedeklerinden, 1.090.958.000 TL'lik kısmı kar yedeklerinden, 106.614.000 TL'lik kısmı kar veya zarar hesabından oluşmaktadır. 2014 faaliyet döneminde, şirketin ödenmiş sermayesi 1.158.000.000 TL olup, şirket 80.000.000 TL'lik sermaye artışına gitmiştir.

Bu çerçevede, Şekerbank Türk A.Ş.'nin 2010-2015 dönemlerine ilişkin finansal verileri bir bütün olarak değerlendirildiğinde, şirketin 2010, 2011, 2014 ve 2015 faaliyet döneminde iç kaynaklardan sermaye artırımında bulunduğu, 2012 ve 2013 faaliyet döneminde herhangi bir sermaye artırımına gitmediği saptanmıştır.

\subsection{Tekstil Bankası A.Ş. (ICBC Turkey Bank)}

Tekstil Bankası A.Ş.'nin 2010 yılı bilançosu incelendiğinde, şirketin özsermaye toplamı 496.544 .000 TL olup bu tutarın 420.000.000 TL'lik kısmı ödenmiş sermayeden, 21.986.000 TL'lik kısmı sermaye yedeklerinden, 34.516.000 TL'lik kısmı kar yedeklerinden, 20.042.000 TL'lik kısmı kar veya zarar hesabından oluşmaktadır. 2010 faaliyet döneminde, şirketin ödenmiş sermayesi 420.000.000 TL olup şirket bu faaliyet döneminde herhangi bir sermaye artışına gitmemiştir.

Tekstil Bankası A.Ş.'nin 2011 yılı bilançosu incelendiğinde, şirketin özsermaye toplamı 517.790 .000 TL olup bu tutarın 420.000.000 TL'lik kısmı ödenmiş sermayeden, 18.806.000 TL'lik kısmı sermaye yedeklerinden, 54.558.000 TL'lik kısmı kar yedeklerinden, 24.626.000 TL'lik kısmı kar veya zarar hesabından oluşmaktadır. 2011 faaliyet döneminde, şirketin ödenmiş sermayesi 420.000.000 TL olup şirket bu faaliyet döneminde herhangi bir sermaye artışına gitmemiştir.

Tekstil Bankası A.Ş.' nin 2012 yılı bilançosu incelendiğinde, şirketin özsermaye toplamı 574.901.000 TL olup bu tutarın 420.000.000 TL'lik kısmı ödenmiş sermayeden, 49.659.000 TL'lik kısmı sermaye yedeklerinden, 79.184.000 TL'lik kısmı kar yedeklerinden, 26.058.000 TL'lik kısmı kar veya zarar hesabından oluşmaktadır. 2012 faaliyet döneminde, şirketin ödenmiş sermayesi 420.000 .000 TL olup şirket bu faaliyet döneminde herhangi bir sermaye artışına gitmemiştir.

Tekstil Bankası A.Ş.'nin 2013 yılı bilançosu incelendiğinde, şirketin özsermaye toplamı 600.494 .000 TL olup bu tutarın 420.000.000 TL'lik kısmı ödenmiş sermayeden, 33.752.000 TL'lik kısmı sermaye yedeklerinden, 102.929.000 TL'lik kısmı kar yedeklerinden, 43.813.000 TL'lik kısmı kar veya zarar hesabından oluşmaktadır. 2013 faaliyet döneminde, şirketin ödenmiş sermayesi 420.000.000 TL olup şirket bu faaliyet döneminde herhangi bir sermaye artışına gitmemiştir.

Tekstil Bankası A.Ş.' nin 2014 yılı bilançosu incelendiğinde, şirketin özsermaye toplamı 616.132.000 TL olup bu tutarın 420.000.000 TL'lik kısmı ödenmiş sermayeden, 7.377.000 TL'lik kısmı sermaye yedeklerinden, 176.239.000 TL'lik kısmı kar yedeklerinden, 12.516.000 TL'lik kısmı kar veya zarar hesabından oluşmaktadır. 2014 faaliyet döneminde, şirketin ödenmiş sermayesi 420.000.000 TL olup şirket bu faaliyet döneminde herhangi bir sermaye artışına gitmemiştir.

Tekstil Bankası A.Ş.' nin 2015 yılı bilançosu incelendiğinde, şirketin özsermaye toplamı 589.665.000TL olup bu tutarın 420.000.000 TL'lik kısmı ödenmiş sermayeden, -2.074.000 TL'lik kısmı sermaye yedeklerinden, 188.755.000 TL'lik kısmı kar yedeklerinden, -17.016.000 TL'lik kısmı kar veya zarar hesabından oluşmaktadır. 2015 faaliyet döneminde, şirketin ödenmiş sermayesi 420.000.000 TL olup şirket bu faaliyet döneminde herhangi bir sermaye artışına gitmemiştir.

Bu çerçevede, Tekstil Bankası A.Ş.'nin 2010-2015 dönemlerine ilişkin finansal verileri bir bütün olarak değerlendirildiğinde, şirketin ilgili faaliyet dönemlerinde herhangi bir sermaye artırımına gitmediği belirlenmiştir.

\subsection{Türkiye Sınai Kalkınma Bankası A.Ş.}

Türkiye Sınai Kalkınma Bankası A.Ş.'nin 2010 yılı bilançosu incelendiğinde, şirketin özsermaye toplamı 1.398.521.000 TL olup bu tutarın 700.000.000 TL'lik kısmı ödenmiş sermayeden, 100.980.000 TL'lik kısmı sermaye yedeklerinden, 233.846.000 TL'lik kısmı kar yedeklerinden, 263.779.000 TL'lik kısmı kar veya zarar hesabından, 99.916.000 TL'lik kısmı ise azınlık paylarından oluşmaktadır. Cari dönemde 25 Mart 2010 tarihinde yapılan Olağan Genel Kurul toplantısında alınan karar doğrultusunda, Ana Ortaklık Banka'nın 600.000.000 TL tutarındaki ödenmiş sermayesinin toplam 100.000.000 TL artıılarak 700.000.000 TL'ye yükseltilmesine, artışın 85.000.000 TL'lik kısmının 2009 yılı karından, kalan 15.000.000 TL'lik kısmının ise olağanüstü yedeklerden karşılanmasına karar verilmiştir.

Türkiye Sınai Kalkınma Bankası A.Ş.' nin 2011 yılı bilançosu incelendiğinde, şirketin özsermaye toplamı 1.557.101.000 TL olup bu tutarın 800.000.000 TL'lik kısmı ödenmiş sermayeden, 49.121.000 TL'lik kısmı sermaye yedeklerinden, 300.572.000 TL'lik kısmı kar yedeklerinden, 310.617.000 TL'lik kısmı kar veya zarar hesabından, 96.791.000 TL'lik kısmı ise azınlık paylarından oluşmaktadır. Cari dönemde 25 Mart 2011 tarihinde yapılan Olağan Genel Kurul toplantısında alınan karar 
doğrultusunda, Ana ortaklık Banka'nın 700.000.000 TL tutarındaki çıkarılmış sermayesinin toplam 100.000.000 TL artırılarak 800.000.000 TL'ye yükseltilmesine, artışın 100.000.000 TL'lik kısmının 2010 yılı karından karşılanmasına karar verilmiştir.

Türkiye Sınai Kalkınma Bankası A.Ş.' nin 2012 yılı bilançosu incelendiğinde, şirketin özsermaye toplamı 1.919.002.000 TL olup bu tutarın 1.100.000.000 TL'lik kısmı ödenmiş sermayeden, 169.673.000 TL'lik kısmı sermaye yedeklerinden, 195.793.000 TL'lik kısmı kar yedeklerinden, 369.263.000 TL'lik kısmı kar veya zarar hesabından, 84.273.000 TL'lik kısmı ise azınlık paylarından oluşmaktadır. Cari dönemde 26 Mart 2012 tarihinde yapılan Olağan Genel Kurul toplantısında alınan karar doğrultusunda, Ana ortaklık Banka'nın 800.000.000 TL tutarındaki ödenmiş sermayesinin toplam 300.000.000 TL artırılarak 1.100.000.000TL'ye yükseltilmesine, artışın 137.000.000 TL'lik kısmının 2011 yılı kârından, geri kalan 163.000.000 TL'lik kısmının olağanüstü yedeklerden karşılanmasına karar verilmiştir.

Türkiye Sınai Kalkınma Bankası A.Ş.' nin 2013 yılı bilançosu incelendiğinde, şirketin özsermaye toplamı 2.017.534.000 TL olup bu tutarın 1.300.000.000 TL'lik kısmı ödenmiş sermayeden, 13.723.000 TL'lik kısmı sermaye yedeklerinden, 262.400.000 TL'lik kısmı kar yedeklerinden, 365.889.000 TL'lik kısmı kar veya zarar hesabından, 75.522.000 TL'lik kısmı ise azınlık paylarından oluşmaktadır. Cari dönemde, 26 Mart 2013 tarihinde yapılan Olağan Genel Kurul toplantısında alınan karar doğrultusunda, Ana ortaklık Banka'nın 1.100.000.000 TL tutarındaki ödenmiş sermayesinin toplam 200.000.000 TL artırılarak 1.300.000.000 TL'ye yükseltilmesine, artışın 168.000.000 TL'lik kısmının 2012 yılı kârından, geri kalan 32.000.000 TL'lik kısmının olağanüstü yedeklerden karşılanmasına karar verilmiştir.

Türkiye Sınai Kalkınma Bankası A.Ş.' nin 2014 yılı bilançosu incelendiğinde, şirketin özsermaye toplamı 2.288.085.000 TL olup bu tutarın 1.500.000.000 TL'lik kısmı ödenmiş sermayeden, 112.320.000 TL'lik kısmı sermaye yedeklerinden, 306.491.000 TL'lik kısmı kar yedeklerinden, 369.274.000 TL'lik kısmı kar veya zarar hesabından, 67.453.000 TL'lik kısmı ise azınlık paylarından oluşmaktadır. Ayrıca cari dönemde, 27 Mart 2014 tarihinde yapılan Olağan Genel Kurul toplantısında alınan karar doğrultusunda, Ana ortaklık Banka'nın 1.500.000 TL tutarındaki ödenmiş sermayesinin toplam 200.000 TL artırılarak 1.500.000 TL'ye yükseltilmesine, artışın tamamının Genel Kurul Kararı çerçevesinde 2013 yılı kârından karşılanmasına karar verilmiştir. Söz konusu artış, 16 Nisan 2014 tarihli BDDK yazısı ile onaylanmış olup, 21 Mayıs 2014 tarih ve 8573 sayılı Türkiye Ticaret Sicili Gazetesi'nde ilan edilmiştir.

Türkiye Sınai Kalkınma Bankası A.Ş.' nin 2014 yılı bilançosu incelendiğinde, şirketin özsermaye toplamı 2.488.727.000 TL olup bu tutarın 1.750.000.000 TL'lik kısmı ödenmiş sermayeden, -21.940.000 TL'lik kısmı sermaye yedeklerinden, 353.822.000 TL'lik kısmı kar yedeklerinden, 406.845.000 TL'lik kısmı kar veya zarar hesabından oluşmaktadır. 2015 faaliyet döneminde, şirketin ödenmiş sermayesi 2.488.727.000 TL olup şirket bu faaliyet döneminde herhangi bir sermaye artışına gitmemiştir.

Bu çerçevede, Türkiye Sınai Kalkınma Bankası A.Ş.'nin 2010-2015 dönemlerine ilişkin finansal verileri bir bütün olarak değerlendirildiğinde, şirketin 2015 faaliyet dönemi hariç diğer dönemlerde iç kaynaklardan sermaye artırımında bulunduğu tespit edilmiştir.

\subsection{Türk Ekonomi Bankası A.Ş.}

Türk Ekonomi Bankası A.Ş.'nin 2010 yılı bilançosu incelendiğinde, şirketin özsermaye toplamı 1.953.254.000 TL olup bu tutarın 1.100.000.000 TL'lik kısmı ödenmiş sermayeden, 86.176.000 TL'lik kısmı sermaye yedeklerinden, 494.459.000 TL'lik kısmı kar yedeklerinden, 272.619.000 TL'lik kısmı kar veya zarar hesabından oluşmaktadır. 2010 faaliyet döneminde, şirketin ödenmiş sermayesi 1.100.000.000 TL olup şirket bu faaliyet döneminde herhangi bir sermaye artışına gitmemiştir.

Türk Ekonomi Bankası A.Ş.' nin 2011 yılı bilançosu incelendiğinde, şirketin özsermaye toplamı 4.430.778.000 TL olup bu tutarın 2.204.390.000 TL'lik kısmı ödenmiş sermayeden, 672.762.000 TL'lik kısmı sermaye yedeklerinden, 1.306.546.000 TL'lik kısmı kar yedeklerinden, 234.061.000 TL'lik kısmı kar veya zarar hesabından, 13.019.000 TL'lik kısmı ise azınlık paylarından oluşmaktadır. Bankacılık Düzenleme ve Denetleme Kurumu'nun 10 Şubat 2011 tarihli izninin 12 Şubat 2011 tarih ve 27844 sayılı Resmi Gazete'de yayımlanmasını müteakip, 14 Şubat 2011 tarihinde İstanbul Ticaret Sicili'ne yapılan tescil ile Fortis Bank A.Ş.'nin tüzel kişiliğinin sona erdirilmesi suretiyle tüm hak, alacak, borç ve yükümlülükleri (aktif ve pasifi) ile kül halinde Ana Ortaklık Banka'ya devri yoluyla iki bankanın birleştirilmesi gerçekleştirilmiştir. Birleşme dolayısıyla Ana Ortaklık Banka kayıtlı sermaye tavanı 1.400.000.000 TL'den 2.204.390.000 TL'ye, 1.100.000.000 TL'lik çıkarılmış sermayesi de 1.104.390.000 TL artışla 2.204.390.000 TL'ye yükseltilmiştir. 1.104.390.000 TL tutarın 1.050.000.000 TL 'lik kısmı devir dolayısıyla, 54.390.000 TL ise kar yedeklerinden karşılanmıştır.

Türk Ekonomi Bankası A.Ş.' nin 2012 yılı bilançosu incelendiğinde, şirketin özsermaye toplamı 4.999.764.000 TL olup bu tutarın 2.204.390.000 TL'lik kısmı ödenmiş sermayeden, 780.725.000 TL'lik kısmı sermaye yedeklerinden, 1.521.020.000 TL'lik kısmı kar yedeklerinden, 485.297.000 TL'lik kısmı kar veya zarar hesabından, 7.702.000 TL'lik kısmı ise azınlık paylarından oluşmaktadır. 2012 faaliyet döneminde, şirketin ödenmiş sermayesi 2.204.390.000 TL olup şirket bu faaliyet döneminde herhangi bir sermaye artışına gitmemiştir. 
Türk Ekonomi Bankası A.Ş.'nin 2013 yılı bilançosu incelendiğinde, şirketin özsermaye toplamı 5.823.880.000 TL olup bu tutarın 2.204.390.000 TL'lik kısmı ödenmiş sermayeden, 721.988.000 TL'lik kısmı sermaye yedeklerinden, 1.815 .515 .000 TL'lik kısmı kar yedeklerinden, 544.545.000 TL'lik kısmı kar veya zarar hesabından oluşmaktadır. 2013 faaliyet döneminde, şirketin ödenmiş sermayesi 2.204.390.000 TL olup şirket bu faaliyet döneminde herhangi bir sermaye artışına gitmemiştir.

Türk Ekonomi Bankası A.Ş.'nin 2014 yılı bilançosu incelendiğinde, şirketin özsermaye toplamı 5.902.979.000 TL olup bu tutarın 2.204.390.000 TL'lik kısmı ödenmiş sermayeden, 706.569.000 TL'lik kısmı sermaye yedeklerinden, 2.359.963.000 TL'lik kısmı kar yedeklerinden, 632.057.000 TL'lik kısmı kar veya zarar hesabından oluşmaktadır. 2014 faaliyet döneminde, şirketin ödenmiş sermayesi 2.204.390.000 TL olup şirket bu faaliyet döneminde herhangi bir sermaye artışına gitmemiştir.

Türk Ekonomi Bankası A.Ş.'nin 2015 yılı bilançosu incelendiğinde, şirketin özsermaye toplamı 6.961.824.000TL olup bu tutarın 2.204.390.000 TL'lik kısmı ödenmiş sermayeden 887.994.000 TL'lik kısmı sermaye yedeklerinden, 2.359.963.000 TL'lik kısmı kar yedeklerinden, 891.950.000 TL'lik kısmı kar veya zarar hesabından oluşmaktadır. 2015 faaliyet döneminde, şirketin ödenmiş sermayesi 2.204.390.000 TL olup şirket bu faaliyet döneminde herhangi bir sermaye artışına gitmemiştir.

Bu çerçevede, Türk Ekonomi Bankası A.Ş.'nin 2010-2015 dönemlerine ilişkin finansal verileri bir bütün olarak değerlendirildiğinde, şirketin 2010, 2012, 2013, 2014 ve 2015 faaliyet dönemlerinde herhangi bir sermaye artırımına gitmediği, 2011 faaliyet döneminde ise hem iç kaynak, hem de dış kaynaklardan sermaye artırımına gittiği tespit edilmiştir.

\subsection{Türkiye Vakıflar Bankası Türk A.Ş.}

Türkiye Vakıflar Bankası Türk A.Ş.'nin 2010 yılı bilançosu incelendiğinde, şirketin özsermaye toplamı 8.579.083.000 TL olup bu tutarın 2.500.000.000 TL'lik kısmı ödenmiş sermayeden, 1.034.556.000 TL'lik kısmı sermaye yedeklerinden, 3.596.830.000 TL'lik kısmı kar yedeklerinden, 1.204.907.000 TL'lik kısmı kar veya zarar hesabından, 242.790.000 TL'lik kısmı ise azınlık paylarından oluşmaktadır. 2010 faaliyet döneminde, şirketin ödenmiş sermayesi 2.500.000.000 TL olup şirket bu faaliyet döneminde herhangi bir sermaye artışına gitmemiştir.

Türkiye Vakıflar Bankası Türk A.Ş.'nin 2011 yılı bilançosu incelendiğinde, şirketin özsermaye toplamı 9.598.202.000 TL olup bu tutarın 2.500.000.000 TL'lik kısmı ödenmiş sermayeden, 651.557.000 TL'lik kısmı sermaye yedeklerinden, 4.753.995.000 TL'lik kısmı kar yedeklerinden, 1.333.600.000 TL'lik kısmı kar veya zarar hesabından, 359.050.000 TL'lik kısmı ise azınlık paylarından oluşmaktadır. 2011 faaliyet döneminde, şirketin ödenmiş sermayesi 2.500.000.000 TL olup şirket bu faaliyet döneminde herhangi bir sermaye artışına gitmemiştir.

Türkiye Vakıflar Bankası Türk A.Ş.'nin 2012 yılı bilançosu incelendiğinde, şirketin özsermaye toplamı 11.828.997.000 TL olup bu tutarın 2.500.000.000 TL'lik kısmı ödenmiş sermayeden, 1.499.762.000 TL'lik kısmı sermaye yedeklerinden, 5.913.527.000 TL'lik kısmı kar yedeklerinden, 1.518.089.000 TL'lik kısmı kar veya zarar hesabından, 397.619.000 TL'lik kısmı ise azınlık paylarından oluşmaktadır. 2012 faaliyet döneminde, şirketin ödenmiş sermayesi 2.500.000.000 TL olup şirket bu faaliyet döneminde herhangi bir sermaye artışına gitmemiştir.

Türkiye Vakıflar Bankası Türk A.Ş.'nin 2013 yılı bilançosu incelendiğinde, şirketin özsermaye toplamı 12.616.321.000 TL olup bu tutarın 2.500.000.000 TL'lik kısmı ödenmiş sermayeden, 1.521.201.000 TL'lik kısmı sermaye yedeklerinden, 7.009.581.000 TL'lik kısmı kar yedeklerinden, 1.585.539.000 TL'lik kısmı kar veya zarar hesabından, 309.101.000 TL'lik kısmı ise azınlık paylarından oluşmaktadır. 2013 faaliyet döneminde, şirketin ödenmiş sermayesi 2.500.000.000 TL olup şirket bu faaliyet döneminde herhangi bir sermaye artışına gitmemiştir.

Türkiye Vakıflar Bankası Türk A.Ş.'nin 2014 yılı bilançosu incelendiğinde, şirketin özsermaye toplamı 14.771.750.000 TL olup bu tutarın 2.500.000.000 TL'lik kısmı ödenmiş sermayeden, 2.055.746.000 TL'lik kısmı sermaye yedeklerinden, 8.462.731.000 TL'lik kısmı kar yedeklerinden, 1.753.273.000 TL'lik kısmı kar veya zarar hesabından, 486.084.000 TL'lik kısmı ise azınlık paylarından oluşmaktadır. 2014 faaliyet döneminde, şirketin ödenmiş sermayesi 2.500.000.000 TL olup şirket bu faaliyet döneminde herhangi bir sermaye artışına gitmemiştir.

Türkiye Vakıflar Bankası Türk A.Ş.'nin 2015 yılı bilançosu incelendiğinde, şirketin özsermaye toplamı 17.002.755.000 TL olup bu tutarın 2.500.000.000 TL'lik kısmı ödenmiş sermayeden, 2.403.441.000 TL'lik kısmı sermaye yedeklerinden, 10.333.662.000 TL'lik kısmı kar yedeklerinden, 2.015.941.000 TL'lik kısmı kar veya zarar hesabından, 505.391.000 TL'lik kısmı ise azınlık paylarından oluşmaktadır. 2015 faaliyet döneminde, şirketin ödenmiş sermayesi 2.500.000.000 TL olup şirket bu faaliyet döneminde herhangi bir sermaye artışına gitmemiştir.

Bu çerçevede, Türkiye Vakıflar Bankası Türk A.Ş.'nin 2010-2015 dönemlerine ilişkin finansal verileri bir bütün olarak değerlendirildiğinde, şirketin bu faaliyet dönemlerinde herhangi bir sermaye artırımına gitmediği anlaşılmıştır. 


\subsection{Yapı ve Kredi Bankası A.Ş.}

Yapı ve Kredi Bankası A.Ş.' nin 2010 yılı bilançosu incelendiğinde, şirketin özsermaye toplamı 10.745.769.000 TL olup bu tutarın 4.347.051.000 TL'lik kısmı ödenmiş sermayeden, 733.973.000 TL'lik kısmı sermaye yedeklerinden, 3.202.502.000 TL'lik kısmı kar yedeklerinden, 2.399.148.000 TL'lik kısmı kar veya zarar hesabından, 63.095.000 TL'lik kısmı ise azınlık paylarından oluşmaktadır. 2010 faaliyet döneminde, şirketin ödenmiş sermayesi 4.347.051.000 TL olup şirket bu faaliyet döneminde herhangi bir sermaye artışına gitmemiştir.

Yapı ve Kredi Bankası A.Ş.'nin 2011 yılı bilançosu incelendiğinde, şirketin özsermaye toplamı 12.635.234.000 TL olup bu tutarın 4.347.051.000 TL'lik kısmı ödenmiş sermayeden, 400.342.000 TL'lik kısmı sermaye yedeklerinden, 5.197.101.000 TL'lik kısmı kar yedeklerinden, 2.623.652.000 TL'lik kısmı kar veya zarar hesabından, 67.178.000 TL'lik kısmı ise azınlık paylarından oluşmaktadır. 2011 faaliyet döneminde, şirketin ödenmiş sermayesi 4.347.051.000 TL olup şirket bu faaliyet döneminde herhangi bir sermaye artışına gitmemiştir.

Yapı ve Kredi Bankası A.Ş.'nin 2012 yılı bilançosu incelendiğinde, şirketin özsermaye toplamı 16.039.538.000 TL olup bu tutarın 4.347.051.000 TL'lik kısmı ödenmiş sermayeden, 1.667.446.000 TL'lik kısmı sermaye yedeklerinden, 7.118.712.000 TL'lik kısmı kar yedeklerinden, 2.841.517.000 TL'lik kısmı kar veya zarar hesabından, 64.792.000 TL'lik kısmı ise azınlık paylarından oluşmaktadır. 2012 faaliyet döneminde, şirketin ödenmiş sermayesi 4.347.051.000 TL olup şirket bu faaliyet döneminde herhangi bir sermaye artışına gitmemiştir.

Yapı ve Kredi Bankası A.Ş.'nin 2013 yılı bilançosu incelendiğinde, şirketin özsermaye toplamı 17.308.949.000 TL olup bu tutarın 4.347.051.000 TL'lik kısmı ödenmiş sermayeden, 1.228.451.000 TL'lik kısmı sermaye yedeklerinden, 8.530.472.000 TL'lik kısmı kar yedeklerinden, 3.202.975.000 TL'lik kısmı kar veya zarar hesabından, 2.527.000 TL'lik kısmı ise azınlık paylarından oluşmaktadır. 2013 faaliyet döneminde, şirketin ödenmiş sermayesi 4.347.051.000 TL olup şirket bu faaliyet döneminde herhangi bir sermaye artışına gitmemiştir.

Yapı ve Kredi Bankası A.Ş.'nin 2014 yılı bilançosu incelendiğinde, şirketin özsermaye toplamı 20.217.699.000 TL olup bu tutarın 4.347.051.000 TL'lik kısmı ödenmiş sermayeden, 3.356.183.000 TL'lik kısmı sermaye yedeklerinden, 10.457.954.000 TL'lik kısmı kar yedeklerinden, 2.056.511.000 TL'lik kısmı kar veya zarar hesabından, 462.000 TL'lik kısmı ise azınlık paylarından oluşmaktadır. 2014 faaliyet döneminde, şirketin ödenmiş sermayesi 4.347.051.000 TL olup şirket bu faaliyet döneminde herhangi bir sermaye artışına gitmemiştir.

Yapı ve Kredi Bankası A.Ş.'nin 2015 yılı bilançosu incelendiğinde, şirketin özsermaye toplamı 23.084.011.000 TL olup bu tutarın 4.347.050.000 TL'lik kısmı ödenmiş sermayeden, 4,975.060.000 TL'lik kısmı sermaye yedeklerinden, 11.901.355.000 TL'lik kısmı kar yedeklerinden, 1.860.545.000 TL'lik kısmı kar veya zarar hesabından oluşmaktadır. 2015 faaliyet döneminde, şirketin ödenmiş sermayesi 4.347.051.000 TL olup şirket bu faaliyet döneminde herhangi bir sermaye artışına gitmemiştir.

Bu çerçevede, Yapı ve Kredi Bankası A.Ş.'nin 2010-2015 dönemlerine ilişkin finansal verileri bir bütün olarak değerlendirildiğinde, şirketin bu faaliyet dönemlerinde herhangi bir sermaye artırımına gitmediği anlaşıımıştır.

Yukarıda verilen bilgiler kapsamında, aşağıda yer alan Tablo 3 kapsamında 2010-2015 yılları arasında analiz kapsamındaki bankaların sermaye artışı yapıp yapmadıkları konusunda özet bilgiler verilmiştir.

Tablo 3: Araştırma Kapsamındaki Bankaların Sermaye Artışlarına ilişsin Genel Bilgiler (2010-2015)

\begin{tabular}{|c|c|c|c|c|c|c|}
\hline Bankalar / Yıllar & 2010 & 2011 & 2012 & 2013 & 2014 & 2015 \\
\hline Akbank & \begin{tabular}{|c|} 
İç Kaynaklardan \\
1.000 .000 .000 \\
TL
\end{tabular} & - & - & - & - & - \\
\hline Alternatif Bank & - & - & \begin{tabular}{|c|} 
İç \\
Kaynaklardan \\
120.000 .000 \\
TL \\
\end{tabular} & - & - & - \\
\hline Albaraka Türk Katılım Bankası & - & - & $\begin{array}{c}\text { İç } \\
\text { Kaynaklardan } \\
361.000 .000 \\
\text { TL }\end{array}$ & - & - & - \\
\hline Finansbank & \begin{tabular}{|c|} 
İç Kaynaklardan \\
$82.857 .000 \mathrm{TL}$
\end{tabular} & $\begin{array}{c}\text { İç } \\
\text { Kaynaklardan }\end{array}$ & \begin{tabular}{c|c|} 
İç \\
Kaynaklardan
\end{tabular} & $\begin{array}{c}\text { İ̧̧ } \\
\text { Kaynaklardan }\end{array}$ & Yok & Yok \\
\hline
\end{tabular}




\begin{tabular}{|c|c|c|c|c|c|c|}
\hline & \begin{tabular}{|c|} 
Sermaye \\
Taahhüdü İle \\
$547.143 .000 \mathrm{TL}$
\end{tabular} & $\begin{array}{c}118.667 .000 \\
\text { TL } \\
\text { Sermaye } \\
\text { Taahhüdü İle } \\
\text { 116.333.000 } \\
\text { TL } \\
\end{array}$ & $\begin{array}{c}125.000 .000 \\
T L\end{array}$ & $\begin{array}{c}135.000 .000 \\
\text { TL }\end{array}$ & & \\
\hline Garanti Bankası & - & - & - & - & - & - \\
\hline Türkiye Halk Bankası & - & - & - & - & - & - \\
\hline Türkiye İş Bankası & \begin{tabular}{|c|} 
İç Kaynaklardan \\
1.420 .361 .000 \\
TL \\
\end{tabular} & - & - & - & - & - \\
\hline Şekerbank Türk & $\begin{array}{l}\text { İç Kaynaklardan } \\
250.000 .000 \mathrm{TL}\end{array}$ & $\begin{array}{c}\text { İç } \\
\text { Kaynaklardan } \\
250.000 .000 \\
\text { TL }\end{array}$ & - & - & $\begin{array}{c}\text { İç } \\
\text { Kaynaklardan } \\
87.187 .000 \mathrm{TL}\end{array}$ & $\begin{array}{c}\text { İç } \\
\text { Kaynaklardan } \\
80.000 .000 \mathrm{TL}\end{array}$ \\
\hline Tekstil Bankası & - & - & - & - & - & - \\
\hline $\begin{array}{l}\text { Türkiye Sınai Kalkınma } \\
\text { Bankası }\end{array}$ & $\begin{array}{l}\text { İç Kaynaklardan } \\
100.000 .000 \mathrm{TL}\end{array}$ & $\begin{array}{c}\text { İç } \\
\text { Kaynaklardan } \\
100.000 .000 \\
\text { TL }\end{array}$ & $\begin{array}{c}\text { İç } \\
\text { Kaynaklardan } \\
300.000 .000 \\
\text { TL }\end{array}$ & $\begin{array}{c}\text { İç } \\
\text { Kaynaklardan } \\
200.000 .000 \\
\text { TL }\end{array}$ & $\begin{array}{c}\text { İç } \\
\text { Kaynaklardan } \\
200.000 .000 \\
\text { TL }\end{array}$ & - \\
\hline Türk Ekonomi Bankası & - & \begin{tabular}{|c|} 
İç \\
Kaynaklardan \\
1.050 .000 .000 \\
TL \\
Sermaye \\
Taahhüdü ile \\
$54.390 .000 \mathrm{TL}$ \\
\end{tabular} & - & - & - & - \\
\hline Türkiye Vakıflar Bankası Türk & - & - & - & - & - & - \\
\hline Yapı ve Kredi Bankası & - & - & - & - & - & - \\
\hline
\end{tabular}

Yukarıdaki tabloda, çalışma kapsamına alınan bankaların 2010-2015 arasındaki 6 yıllık dönemde sermaye artırımına gidip gitmedikleri özet halinde verilmiş olup, söz konusu dönemde sermaye artımına giden bankaların hangi yöntemleri kullandıkları aşağıda detaylı olarak verilmiştir. Buna göre;

$\checkmark$ Akbank T.A.Ş.'nin 2010-2015 dönemlerine ilişkin finansal verileri bir bütün olarak değerlendirildiğinde, şirketin 2010 yılında iç kaynaklardan sermaye artırımına gittiği, 2011, 2012, 2013, 2014 ve 2015 faaliyet dönemlerinde herhangi bir sermaye artırımına gitmediği,

$\checkmark$ Alternatifbank A.Ş.'nin 2010-2015 dönemlerine ilişkin finansal verileri bir bütün olarak değerlendirildiğinde, şirketin 2010, 2011, 2013, 2014 ve 2015 faaliyet dönemlerinde herhangi bir sermaye artırımına gitmediği, 2012 faaliyet döneminde ise iç kaynaklardan sermaye artırımına gittiği,

$\checkmark$ Albaraka Türk Katılım Bankası A.Ş.'nin 2010-2015 dönemlerine ilişkin finansal verileri bir bütün olarak değerlendirildiğinde, şirketin 2010, 2011, 2013, 2014 ve 2015 faaliyet dönemlerinde herhangi bir sermaye artırımına gitmediği, 2012 faaliyet döneminde ise iç kaynaklardan sermaye artırımına gittiği,

$\checkmark$ Finansbank A.Ş.'nin 2010-2015 dönemlerine ilişkin finansal verileri bir bütün olarak değerlendirildiğinde, şirketin 2010, 2011, 2014 ve 2015 faaliyet dönemlerinde hem iç kaynaklardan hem dış kaynaklardan, 2012 ve 2013 faaliyet dönemlerinde ise yalnızca iç kaynaklardan sermaye artırımında bulunduğu,

$\checkmark$ Garanti Bankası A.Ş.'nin 2010-2015 dönemlerine ilişkin finansal verileri bir bütün olarak değerlendirildiğinde, şirketin ilgili faaliyet dönemlerinde herhangi bir sermaye artırımına gitmediği,

$\checkmark$ Türkiye Halk Bankası A.Ş.'nin 2010-2015 dönemlerine ilişkin finansal verileri bir bütün olarak değerlendirildiğinde, şirketin ilgili faaliyet dönemlerinde herhangi bir sermaye artırımına gitmediği,

$\checkmark$ Türkiye İş Bankası A.Ş.'nin 2010-2015 dönemlerine ilişkin finansal verileri bir bütün olarak değerlendirildiğinde, şirketin 2010 faaliyet döneminde iç kaynaklardan sermaye artırımında bulunduğu, 2011, 2012, 2013, 2014 ve 2015 faaliyet döneminde herhangi bir sermaye artırımına gitmediği,

$\checkmark$ Şekerbank Türk A.Ş.'nin 2010-2015 dönemlerine ilişkin finansal verileri bir bütün olarak değerlendirildiğinde, şirketin 2010, 2011 ve 2015 faaliyet döneminde iç kaynaklardan sermaye artırımında bulunduğu, 2012, 2013 ve 2014 faaliyet döneminde herhangi bir sermaye artırımına gitmediği,

$\checkmark$ Tekstil Bankası A.Ş.'nin 2010-2015 dönemlerine ilişkin finansal verileri bir bütün olarak değerlendirildiğinde, şirketin ilgili faaliyet dönemlerinde herhangi bir sermaye artırımına gitmediği, 
$\checkmark$ Türkiye Sınai Kalkınma Bankası A.Ş’nin 2010-2015 dönemlerine ilişkin finansal verileri bir bütün olarak değerlendirildiğinde, şirketin 2011, 2013 ve 2015 faaliyet dönemlerinde herhangi bir sermaye artırımına gitmediği, şirketin 2010 ve 2014 faaliyet dönemlerinde ise iç kaynaklardan sermaye artırımında bulunduğu,

$\checkmark$ Türk Ekonomi Bankası A.Ş.'nin 2010-2015 dönemlerine ilişkin finansal verileri bir bütün olarak değerlendirildiğinde, şirketin 2010, 2012, 2013, 2014 ve 2015 faaliyet dönemlerinde herhangi bir sermaye artırımına gitmediği, 2011 faaliyet döneminde ise hem iç kaynak, hem de dış kaynaklardan sermaye artırımına gittiği,

$\checkmark$ Türkiye Vakıflar Bankası Türk A.Ş.'nin 2010-2015 dönemlerine ilişkin finansal verileri bir bütün olarak değerlendirildiğinde, şirketin ilgili faaliyet dönemlerinde herhangi bir sermaye artırımına gitmediği,

$\checkmark$ Yapı ve Kredi Bankası A.Ş.'nin 2010-2015 dönemlerine ilişkin finansal verileri bir bütün olarak değerlendirildiğinde, şirketin ilgili faaliyet dönemlerinde herhangi bir sermaye artırımına gitmediği görülmüştür.

Bu çerçevede, inceleme kapsamında alınan 13 bankadan; 6 bankanın iç kaynaklardan sermaye artırımına gittiği, 2 bankanın hem iç kaynaklardan hem dış kaynaklardan sermaye artırımında bulunduğu, şarta bağlı sermaye artırımının hiçbir banka tarafından benimsenmediği, 6 bankanın sermaye artırımına gitmediği tespit edilmiştir.

Yukarıda verilen bilgiler kapsamında Tablo 4'de 2010-2015 yılları arasında analiz kapsamındaki bankaların sermaye artış tutarları ve hangi faktörlerden kaynaklandığı konusunda özet bilgiler verilmiştir;

Tablo 4: Araştırma Kapsamındaki Bankaların Sermaye Artırım Şekilleri ve Tutarına İlişkin Genel Bilgiler (2010-2015)

\begin{tabular}{|c|c|c|c|c|c|c|}
\hline $\begin{array}{l}\text { Bankalar / } \\
\text { Yıllar }\end{array}$ & 2010 & 2011 & 2012 & 2013 & 2014 & 2015 \\
\hline Akbank T.A.Ş & $\begin{array}{l}\text { İç Kaynaklardan } \\
\text { Sermaye Artırımı: } \\
483.446 .000 \text { TL'si } \\
\text { olağanüstü } \\
\text { yedeklerden, } \\
16.554 .000 \text { TL'si iştirak } \\
\text { satış kârlarından, } \\
755.000 \text { TL'si } \\
\text { gayrimenkul satış } \\
\text { kârlarından, } \\
500.000 .000 \text { TL'si diğer } \\
\text { sermaye yedeklerinde } \\
\text { yer alan sermaye } \\
\text { enflasyon düzeltme } \\
\text { farkından karşılanmak } \\
\text { üzere toplam= } \\
1.000 .000 .000 \text { TL } \\
\end{array}$ & - & - & - & - & - \\
\hline $\begin{array}{l}\text { Alternatifba } \\
\text { nk A.Ş. }\end{array}$ & - & - & \begin{tabular}{|l|} 
İç kaynaklardan \\
sermaye artırımı: \\
$114.618 .000 \mathrm{TL}$ \\
olağanüstü \\
yedek \\
akçelerden, \\
$5.382 .000 \mathrm{TL}$ \\
geçmiş dönem \\
karından \\
karşılamak üzere \\
toplam= \\
$120.000 .000 \mathrm{TL}$ \\
\end{tabular} & - & - & - \\
\hline $\begin{array}{l}\text { Albaraka } \\
\text { Türk Katılım } \\
\text { Bankası A.Ş. }\end{array}$ & - & - & $\begin{array}{l}\text { İç kaynaklardan } \\
\text { sermaye artırımı: } \\
\text { olağanüstü } \\
\text { yedek } \\
\text { akçelerden } \\
\text { karşılamak üzere } \\
\text { toplam= } \\
361.000 .000 \mathrm{TL} \\
\end{array}$ & - & - & - \\
\hline
\end{tabular}




\begin{tabular}{|c|c|c|c|c|c|c|}
\hline $\begin{array}{l}\text { Finansbank } \\
\text { A.Ş. }\end{array}$ & $\begin{array}{l}\text { iç̧ ve dış kaynaklardan } \\
\text { sermaye artırımı: } \\
547.143 .000 \text { TL'si nakit, } \\
82.857 .000 \text { TL'si } \\
\text { olağanüsütü } \\
\text { yedeklerden } \\
\text { karşılamak üzere } \\
\text { toplam= } 630.000 .000 \\
\text { TL }\end{array}$ & \begin{tabular}{|l|} 
İç ve dış \\
kaynaklardan \\
sermaye artırımı: \\
116.333 .000 \\
TL'si nakit, \\
118.667 .000 \\
TL'si \\
olağanüsütü \\
yedeklerden \\
karşılamak üzere \\
toplam= \\
$235.000 .000 \mathrm{TL}$ \\
\end{tabular} & \begin{tabular}{|l|} 
İç kaynaklardan \\
sermaye artırımı: \\
olağanüstü \\
yedek \\
akçelerden \\
karşılamak üzere \\
toplam= \\
$125.000 .000 \mathrm{TL}$
\end{tabular} & \begin{tabular}{|l|} 
iç kaynaklardan \\
sermaye artırımı: \\
olağanüstü \\
yedek \\
akçelerden \\
karşılamak üzere \\
toplam= \\
135.000 .000
\end{tabular} & - & T- \\
\hline \begin{tabular}{|l|} 
Garanti \\
Bankası A.Ş.
\end{tabular} & - & - & - & - & - & - \\
\hline $\begin{array}{l}\text { Türkiye Halk } \\
\text { Bankası A.Ş. }\end{array}$ & - & - & - & - & - & - \\
\hline $\begin{array}{l}\text { Türkiye İş } \\
\text { Bankası A.Ş. }\end{array}$ & $\begin{array}{l}\text { İç kaynaklardan } \\
\text { sermaye artırımı: } \\
\text { 1.057.425.000 TL'si kar } \\
\text { yedeklerinden, } \\
362.936 .000 \mathrm{TL} \text { 'si } \\
\text { sermaye yedeklerden } \\
\text { karşılamak üzere } \\
\text { toplam= 1.420.361.000 } \\
\text { TL }\end{array}$ & - & - & - & - & - \\
\hline $\begin{array}{l}\text { Şekerbank } \\
\text { Türk A.Ş. }\end{array}$ & $\begin{array}{l}\text { İç kaynaklardan } \\
\text { sermaye artırımı: } \\
162.210 .000 \text { TL'si } \\
\text { olağanüstü } \\
\text { yedeklerden, } \\
59.300 .000 \text { TL'si diğer } \\
\text { sermaye } \\
\text { yedeklerinden, } \\
11.220 .000 \text { TL'si iştirak } \\
\text { satış karından, } \\
5.270 .000 \text { TL'si hisse } \\
\text { senedi ihraç } \\
\text { primlerinden ve } \\
12.000 .000 \text { TL'si Genel } \\
\text { Kurul'da onaylanan } \\
2009 \text { yılı karından } \\
\text { karşılamak üzere } \\
\text { toplam= 250.000.000 } \\
\text { TL }\end{array}$ & \begin{tabular}{|l|} 
İç kaynaklardan \\
sermaye artırımı: \\
$225.000 .000 \mathrm{TL}$ \\
olağanüstü \\
yedeklerden, \\
$25.000 .000 \mathrm{TL}$ \\
geçmiş dönem \\
karlarından, \\
tamamı iç \\
kaynaklardan \\
karşılamak üzere \\
toplam= \\
$250.000 .000 \mathrm{TL}$
\end{tabular} & - & - & $\begin{array}{l}\text { iç̧ } \\
\text { kaynaklardan } \\
\text { sermaye } \\
\text { artıımı: } \\
\text { tamamı } \\
\text { olağanüstü } \\
\text { yedek } \\
\text { akçelerden, } \\
\text { karşılamak } \\
\text { üzere toplam= } \\
\text { 87.187.000 TL }\end{array}$ & $\begin{array}{l}\text { İç } \\
\text { kaynaklardan } \\
\text { sermaye } \\
\text { artırımı: } \\
\text { tamamı } \\
\text { olağanüstü } \\
\text { yedek } \\
\text { akçelerden, } \\
\text { karşılamak } \\
\text { üzere toplam= } \\
\text { 80.00.000 TL }\end{array}$ \\
\hline \begin{tabular}{|l|} 
Tekstil \\
Bankası A.Ş.
\end{tabular} & - & - & - & - & - & - \\
\hline $\begin{array}{l}\text { Türkiye Sınai } \\
\text { Kalkınma } \\
\text { Bankası A.Ş. }\end{array}$ & $\begin{array}{l}\text { İç kaynaklardan } \\
\text { sermaye artırımı: } \\
85.000 .000 \text { TL'lik } \\
\text { kısmının } 2009 \text { yılı } \\
\text { karından, kalan } \\
15.000 .000 \text { TL'lik } \\
\text { kısmının ise olağanüstü } \\
\text { yedeklerden } \\
\text { karşılamak üzere } \\
\text { toplam= 100.000.000 } \\
\text { TL }\end{array}$ & \begin{tabular}{|l|} 
İç kaynaklardan \\
sermaye artırımı: \\
2010 yılı \\
karından \\
karşılamak üzere \\
toplam= \\
100.000 .000 TL.
\end{tabular} & $\begin{array}{l}\text { İç kaynaklardan } \\
\text { sermaye artırımı: } \\
137.000 .000 \\
\text { TL'lik kısmının } \\
2011 \text { yılı } \\
\text { kârından, geri } \\
\text { kalan } \\
163.000 .000 \\
\text { TL'lik kısmının } \\
\text { olağanüstü } \\
\text { yedeklerden }\end{array}$ & \begin{tabular}{|l|} 
İç kaynaklardan \\
sermaye artırımı: \\
168.000 .000 \\
TL'lik kısmının \\
2012 yılı \\
kârından, geri \\
kalan 32.000 .000 \\
TL'lik kısmının \\
olağanüstü \\
yedeklerden \\
karşılamak üzere
\end{tabular} & $\begin{array}{l}\text { i̇ç } \\
\text { kaynaklardan } \\
\text { sermaye } \\
\text { artırımı: } \\
\text { artırımın } \\
\text { tamamının } \\
2013 \text { yılı } \\
\text { kârından } \\
\text { karşılamak } \\
\text { üzere toplam= } \\
\text { 200.000.000 }\end{array}$ & - \\
\hline
\end{tabular}




\begin{tabular}{|c|c|c|c|c|c|c|}
\hline & & & $\begin{array}{l}\text { karşılamak üzere } \\
\text { toplam= } \\
300.000 .000 \mathrm{TL}\end{array}$ & $\begin{array}{l}\text { toplam }= \\
200.000 .000 \mathrm{TL}\end{array}$ & TL & \\
\hline $\begin{array}{l}\text { Türk } \\
\text { Ekonomi } \\
\text { Bankası A.Ş. }\end{array}$ & - & \begin{tabular}{|l|} 
iç ve dış \\
kaynaklardan \\
sermaye artırımı: \\
$1.104 .390 .000 \mathrm{TL}$ \\
tutarın \\
$1.050 .000 .000 \mathrm{TL}$ \\
‘ lik kısmı devir \\
dolayısıyla, \\
$54.390 .000 \mathrm{TL}$ \\
ise kar \\
yedeklerinden \\
karşılamak üzere \\
toplam= \\
$1.104 .390 .000 \mathrm{TL}$ \\
$\mathrm{TL}$
\end{tabular} & 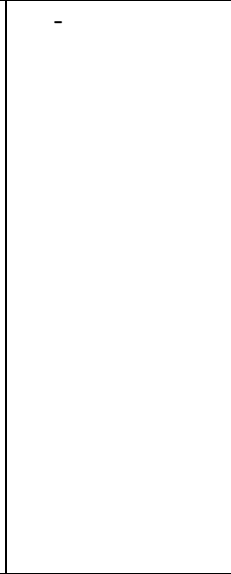 & - & - & \\
\hline \begin{tabular}{|l} 
Türkiye \\
Vakıflar \\
Bankası Türk \\
A.Ş. \\
\end{tabular} & - & - & - & - & - & \\
\hline $\begin{array}{l}\text { Yapı ve Kredi } \\
\text { Bankası A.Ş. }\end{array}$ & - & - & - & - & - & \\
\hline
\end{tabular}

\section{SONUÇ}

Bankalar, ekonominin ve finansal sistemin temel unsuru ve diğer sektörlerle önemli ölçüde bağlantılı olmaları nedeniyle çok önemli bir konuma sahiptirler. Ekonomik büyümenin istikrarlı bir şekilde gerçekleşmesi için kaynakların etkin bir şekilde kullanımına, sağlıklı ve gelişmiş bir finans sektörünün varlığına ihtiyaç duyulmaktadır. Finansal sistemde bir veya birkaç bankanın ödeme güçlügüne düşmesi, performanslarında yaşanan gerilemeler, sektöre duyulan güveni azaltmaktadır. Banka krizlerine maruz kalındığında, bu krizlerin yol açtığı sorunların çözümlenmesi ve tekrar meydana gelmemesi için bazı önlemler alınmaktadır. Bu önlemlerin başında ise düzgün bir bankacılık sistemi için gerekli altyapının ve hukuki düzenlemelerin oluşturulması, etkin bir denetim-gözetim mekanizmasının kurulması ve sektörün performansı, kârlılığı ve sermaye yapısı sürekli izlenmesi gelmektedir. Özellikle bankalarda kuruluş sırasında belirlenen sermayenin şirketin iş kapasitesine göre yetersiz kalması, şirketin iş hacmini genişletmek istemesi, enflasyon nedeniyle paranın satın alma gücünün azalması bu nedenle sermayenin yetersiz kalması, yapılan yanlış yatırımlar ve harcamalar nedeniyle sermayenin azalması, diğer bir görüşe göre yeni yatırımlar için veya şirket faaliyetlerinin reel büyümesi sonucu gereken fon ihtiyacının giderilmesi nedeniyle sermaye artırımına gitme ihtiyacı ortaya çıkabilir. 6102 sayılı TTK'ya göre, şirketlerin üç ayrı sermaye artırım şekli bulunup bunlar; sermaye taahhüdü yoluyla artırım, iç kaynaklardan sermaye artırımı ve şarta bağılı sermaye artırımıdır (Arıçelik, 2010, s. 97).

Bu bağlamda çalışma, 2010-2015 yıllarında BiST'te faaliyet gösteren bankaların sermaye yapılaı ve sermaye artırım şekilleri incelenmiştir. Ayrıca bu bankaların ilgili dönemlerde sermaye artırımına gidip gitmedikleri, gitmişler ise hangi kalemlerin kullanıldığına ve usulüne değinilmiştir. Ulaşılan sonuçlara göre bankacılık sektöründeki şirketlerin çoğunlukla iç kaynaklardan sermaye artırımı yoluna gittiği tespit edilmiştir. Bu sonucun oluşmasında 2000 ve 2001 finansal krizinden sonra gerek BDDK, gerek SPK standartlarıyla çok sıkı takip altına alınan bankaların, bu standartlar nedeniyle ayırdıkları sermaye ve kar yedeklerinin etkisi büyüktür. Bankacılık sektöründeki şirketlerin fazlaca sermaye ve kar yedekleri ayırması, bunlar dolayısıyla güçlü bir özkaynak yapısına sahip olmaları, bu sektördeki şirketlerin sermaye artırımlarını ağılıklı olarak iç kaynaklardan yapıyor olmasının nedenidir. Sektördeki şirketler, büyük ve güçlü şirket olmanın göstergelerinden birisi olan ödenmiş sermaye tutarlarını yüksek göstermek suretiyle güçlü bir mali yapıya sahip olduklarını ortaya koymak amacıyla özkaynakları arasında yer alan ve iç kaynak olarak ifade edilen kaynaklarının bir kısmını ödenmiş sermayeye ekleme yoluna gitmişlerdir. 


\section{KAYNAKÇA}

Arıçelik, G. (2010), Ticari Bankalarda Performans Ölçümü: Camels Analizine Dayalı Bir İnceleme, T.C. Dokuz Eylül Üniversitesi, Sosyal Bilimler Enstitüsü, İktisat Anabilim Dalı, Yayınlanmamış Yüksek Lisans Tezi, İzmir.

Akkale, R. G.(2013), Kayıtlı Sermaye Yapısı Hakkında Genel Bilgi ve 6102 Sayılı Türk Ticaret Kanunu’na Göre Halka Açık Olmayan Anonim Şirketlerde Sermaye Artırım Usulü, Gazi Üniversitesi Hukuk Fakültesi Dergisi, C. XVII.

Bahtiyar, M. (1996), Anonim Ortaklıkta Kayıtlı Sermaye Sistemi ve Sermaye Artırımı, Beta Yayınları, İstanbul.

Biçer, L. (2010), Anonim Şirketlerde Şartlı Sermaye, İstanbul.

Çağlar, H. (2010), Anonim Şirketlerde Esas Sermayenin Azaltılması, Ankara.

Güçlü, H. M. (2015), Anonim Şirketlerde Şartlı Sermaye Artırımı, T.C. Selçuk Üniversitesi, Sosyal Bilimler Enstitüsü, Özel Hukuk Ana Bilim Dalı, Ticaret Hukuku Bilim Dalı, Yayınlanmamış Yüksek Lisans Tezi, Konya.

İmregün, O. (1989), Anonim Ortaklıklar, Yasa Yayınları, İstanbul.

Kaya, A. (1997), Sermaye Artırımı, 40. Yılında Türk Ticaret Kanunu, İstanbul.

Kendigelen, A. (2012), Yeni Türk Ticaret Kanunu: Değişiklikler, Yenilikler ve İlk Tespitler, 2. Bası, İstanbul.

Koç, Y. Y. (2001), Genel Muhasebe İlkeleri Uygulaması, Tek Düzen Muhasebe Sistemi, Ankara.

Moroğlu, E. (2003), Anonim Ortaklıklarda Esas Sermaye Artırımı, Vedat Kitapçılık, İstanbul.

Pulaşlı, H. (2013), İkincil Mevzuat Çerçevesinde Çıkarılan Yönetmelik ve Tebliğlere ve 6362 Sayılı Sermaye Piyasası Kanununa Göre Hazırlanmış Şirketler Hukuku Genel Esaslar, 2. Bası, Seçkin Yayıncılık, Ankara.

Saraç, T. (2009), Anonim Şirketlerde Şarta Bağlı Sermaye Artırımı, Ankara.

Şengür, D. E. (2011), "Yeni Türk Ticaret Kanunu İle Anonim Şirketlerde Sermaye İle İlgili Getirilen Yenilikler", Mali Çözüm Dergisi, OcakŞubat, 97-119.

Tekinalp, Ü. (2011), Yeni Anonim ve Limited Ortaklıklar Hukuku, Vedat yayınevi, 2. Bası, İstanbul.

Ünsal, E. M. (2004), Makro Iktisada Giriş, Siyasal Kitabevi, Ankara.

http://www.hitasymm.com.tr/yeni-turk-ticaret-kanunu-ile-anonim-sirketlerde-sermaye-ve-sermaye-artirimi-ile-ilgili-getirilen-yenilikler-

http://www.vergimevzuati.org/yeni-ttkna-gore-anonim-sirketlerde-sermaye-arttirimi/

http://yildirimercan.blogspot.com.tr/2013/01/anonim-sirketlerde-sarta-bagl-sermaye.html

http://www.thelira.com/yazar/31/ekrem-oncu/2099 